\title{
Fuel and Emission Efficiency test for locally produced charcoal stoves using charcoal sourced from selected tree species in Adola Woyu District, Ethiopia
}

Getachew Demie Gebre ( $\nabla$ ge.demie1990@gmail.com )

Wondo Genet College of Forestry and Natural Resources https://orcid.org/0000-0001-7428-1579

Ararsa Derese Seboka

WGCF-NR: Wondo Genet College of Forestry and Natural Resources

Original article

Keywords: Charcoal, Cookstoves, Emission, fuel-saving, greenhouse gas, consumption

Posted Date: September 21st, 2021

DOI: https://doi.org/10.21203/rs.3.rs-907850/v1

License: (c) (1) This work is licensed under a Creative Commons Attribution 4.0 International License.

Read Full License 


\section{Fuel and Emission Efficiency test for locally produced charcoal stoves}

\section{2 using charcoal sourced from selected tree species in Adola Woyu}

\section{District, Ethiopia}

$4 \quad$ Getachew Demie Gebre ${ }^{1 *}$ and Ararsa Derese Seboka ${ }^{2}$

$6 \quad I^{*}$ Wondo Genet College of Forestry and Natural Resources, Hawassa University. Department of

7 Environmental Science; P.O.Box: 128, Shashemane, Ethiopia

$8 \quad{ }^{2}$ Wondo Genet College of Forestry and Natural Resources, Hawassa University. Department of

9 General Forestry; P.O.Box: 128, Shashemane, Ethiopia

10 Corresponding author: E-mail: ge.demie1990@gmail.com; mobile: +251912740077

\section{Abstract}

13 Background: Energy plays an indispensable role in social, and economic development. It is 14 primarily obtained from biomass and converted to required energy using traditional stoves in most 15 developing countries. Currently, the market is dominated by different shapes and sizes of locally 16 produced cooking stoves. Their impact on fuel-saving, and emission reduction, however, has not 17 been exhaustively investigated.

18 Objective and Method: Hence, the objective of this study is to test the fuel efficiency and emission 19 reduction potential of locally produced charcoal stoves. Accordingly, four charcoal stoves and 20 three plant species that are commonly used were collected for conducting laboratory tests 21 following a controlled cooking test.

22 Results: The overall findings revealed that about $62.69 \%$ of the respondents use locally produced 23 charcoal stoves compared to the traditional metal stoves (37.31\%). However, individual stove- 
1 wise analysis indicates that traditional metal stoves are majorly used stove type followed by

2 Lakech (29.36\%) and Mirchaye (13.46\%) stoves. Overall, a traditional metal stove consumes a

3 huge amount of fuel (0.23ton/year) which is around 0.0046ha of forest and is responsible for the

4 emission of 77.07ton of $\mathrm{CO}_{2}$ e per year whereas the mean consumption of improved stoves is

5 0.16ton/year which is about 0.0032ha of forest and emits 13.69tons of $\mathrm{CO}_{2}$ e per year.

6 Furthermore, these differences were among improved stoves. Accordingly, the highest annual

7 greenhouse gas emission was recorded by Mirchaye stove (14.64ton of $\mathrm{CO}_{2}$ e) followed by lakech,

8 and kib stoves 13.69, and 12.74ton $\mathrm{CO}_{2}$ e respectively. The types of wood used for charcoal

9 preparation, in addition to stoves types, also have an impact on the amount of fuel consumed and 10 pollutants emitted.

11 Conclusions: Generally improved stoves significantly contribute to reducing emission and fuel 12 consumption which in turn reduces the impact on forest resources, human health, and global 13 warming of the energy sector. Hence, this finding discloses the distribution of these improved 14 stoves for local communities by government and concerned stakeholders to assure affordable and 15 clean energy for all and reducing pressure on forest and human health.

16 Keywords: Charcoal, Cookstoves, Emission, fuel-saving, greenhouse gas, consumption

\section{Introduction}

18 Energy has a multitude of implications and plays an indispensable role in social, and economic 19 development [1], [2]. Currently, at the global level, more than three billion people rely on biomass 20 energy sources for different socio-economic activities[3], [4]. Subsequently, the global energy 21 demand is increasing by $4.6 \%$ in 2021 [3] and is expected to continue to mount in the coming 22 decades with increasing population, industries, and expansion of energy-dissipating economic 23 activities [3], [5]. However, the types of energy resources and demand vary from continent to 
1 continent based on economic development. Accordingly, industrialized countries primarily

2 depend on modern energy while the developing countries, particularly Sub-Saharan African,

3 heavily rely on traditional fuel [6], [7] such as fuelwood, dung, and crop residue, for their energy

4 needs [3], [5], [8].

5 Ethiopia, though endowed with huge energy resource potentials like geothermal, wind power,

6 solar, and hydropower, about $91 \%$ of the population depends on traditional biomass fuels to meet

7 their energy needs [1], [6], [9]-[11]. This was associated with the lack of adequate energy services,

8 low and sporadic income, and unavailability of better energy options in most rural and some urban

9 areas of the country which can also in turn influence the choice of fuels and energy technologies

10 [1]. The dependency on wood-based resources as a source of energy had an adverse impact on

11 human health [12], animal, economic, and environmental. The study of [11], [13]-[15] also

12 substantiated that high reliance on forest resources leads to deforestation, forest degradation,

13 desertification, and future energy crisis. On top of this, dependency on traditional energy sources

14 contributes about 1-2.4 Gt CO2e of greenhouse gas emission and 2-7\% of global anthropogenic

15 emission [16]-[19] which in turn leads to indoor air pollution. Exposure to high concentrations of

16 indoor air pollutants has a potential health effect on women, children, and elders. The study of

17 [20], [21] also pinpointed that higher exposure to smoke from the burning biomass fuel increases

18 the risk of lung cancer in adults and pneumonia in children.

19 To reduce pressure on forest resources, emission of atmospheric pollutants, and other 20 multidimensional impacts of dependence on traditional biomass energy sources coupled with their

21 inefficient conversion system, several strategies had been designed and implemented by concerned

22 bodies of government, and non-government organizations. One such intervention was the 23 development and dissemination of improved cookstoves. The finding of [18], [22], and [23] 
1 affirmed that improved cooking stoves have the potential to reduce fuelwood consumption, wood

2 collection time, tree feeling, and emission of a pollutant that poses serious health impact [24] in

3 the short term and greenhouse gas (GHG) emission in long term. However, due to the cost of

4 improved stoves, community awareness, technical and financial requirements, nationally the

5 development and dissemination of standardized improved cookstoves, particularly charcoal

6 stoves, throughout the country were not effective. Considering the high demand and financial

7 income obtained from the production of stoves, different people and small-scale business

8 organizations had been engaged in the production of charcoal stoves. Consequently, different

9 shapes, sizes, and designs of stoves had been penetrating the local market without checking the

10 standard and quality of their stoves. Even though such engagements from private, small-scale

11 business owners and individuals would increase assess and affordability of the stoves; still there

12 is little empirical evidence associated with their fuel use efficiency and greenhouse gas emission

13 reduction potentials relative to the traditional metal charcoal stoves. Therefore, the objective of

14 this study is to test the fuel efficiency and emission reduction potential of three locally produced,

15 widely available, and commonly used charcoal stoves ("lakech", kib, and "Mirchaye") compared

16 to traditional metal charcoal stoves using charcoal produced from three selected tree species

17 dominantly used for charcoal production in the study area following controlled cooking test.

18 Material and Methods

19 Description of the study area

20 The study was conducted in Adola district of Guji zone, which is located in the central rift valley

21 of Ethiopia. Geographically, the area lies between $5^{\circ} 40^{\prime} \mathrm{N}$ to $6^{\circ} 10^{\prime} \mathrm{N}$ latitude and $38^{\circ} 35^{\prime} \mathrm{E}$ to

$2238^{\circ} 58^{\prime} \mathrm{E}$ longitude. The area has a mono-modal rainfall pattern (Figure 1) with a total normal

23 rainfall of $432 \mathrm{~mm}$. The average temperature and rainfall are $38.7^{\circ} \mathrm{C}$, and $430 \mathrm{~mm}$ respectively. 
1 The district is characterized by forest cover (Anferara forest) which is a remnant natural forest

2 resource that faces great pressure from the surrounding community for charcoal production and

3 other fuelwood energy sources.

\section{$4 \quad$ Description of stoves}

5 The traditional metal charcoal stove (Figure $1 \mathrm{~b}$ ) is the most common and widely used stove for

6 cooking in most parts of urban and semi-urban Ethiopia. It consists of a combustion chamber,

7 grate, pot rest, and primary air opening. All its parts are only made of metal and hence, simple that

8 available in the market with varying shape, design, and size. However, Mirchaye (Figure 1a),

9 lakech (Figure 1c), and kib stoves (Figure 1d) are made from both clay and sheet metals. Their

10 outer coverage including grate and pan seat is made of metal sheet whereas the internal wall is

11 from clay. Even though their size and design vary, they all have combustion chambers and grates.

12 Mirchaye and Kib stove have pan seats. However, the pan seat of Mircheye is made of metal that

13 is internally fixed to a metal sheet whereas that of the Kib stove is made of clay that is internally

14 attached to the clay wall of the stove. These stoves were purposively selected since they are easily

15 available in the local market and are dominantly used by most of the respondents in the study area.

16 Accordingly, traditional metal stoves were used as a control for comparison. 

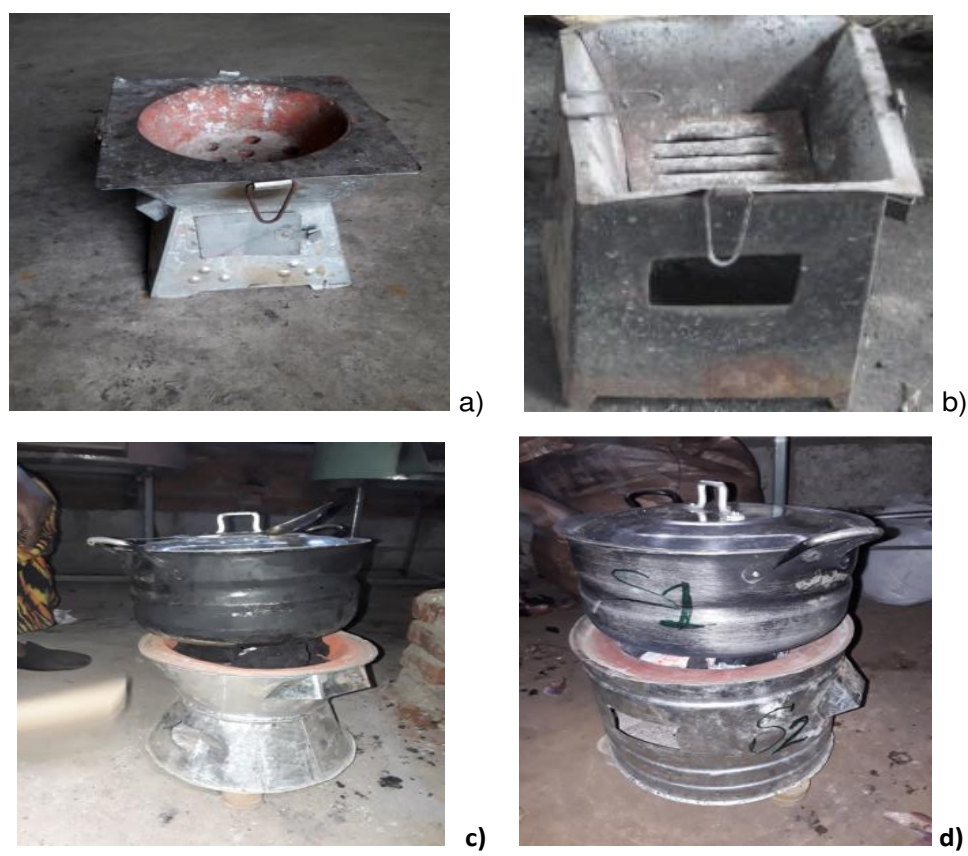

Where: a) Mirchaye

b) traditional metal sheet charcoal stove

c) Lakech

d) Kib charcoal stoves

3

$4 \quad$ Figure 1: Stoves used for fuel and emission test in study area

\section{$5 \quad$ Material and equipment used}

To conduct laboratory analysis and collect the required data, a digital balance with $0.01 \mathrm{gm}$

7 accuracy, digital thermometer with thermocouples, charcoal fuel, sauce ingredients (mitin-Shiro,

8 onion, edible oil, salt, and water), stopwatches, heat resistant hand gloves, charcoal pans, spatulas,

9 measuring tape, wot cooking pot $(25 \mathrm{~cm}$ diameter $)$, emission measuring device, and infrared thermometer were the equipment and materials used during CCT test.

\section{Data Collection}

12 Data was collected from a controlled cooking test (CCT) test, which is carried out in Addis Ababa

13 Laboratory of Alternative Energy Development and Promotion Center, using charcoal derived

14 from three different plant species and stoves. The CCT was conducted to evaluate the fuel use

15 efficiency/performance and emission reduction potential of the commonly used locally produced 
1 charcoal stoves (Mirchaye, Lakech, and $\mathrm{Kib}$ ) relative to the traditional metal charcoal stove.

2 Accordingly, for this test, a standard wot/sauce cooking, which is commonly practiced in the

3 everyday life of households in Ethiopia, was selected for comparing the performance of the

$4 \quad$ selected stoves.

\section{Test Procedure}

6 Control Cooking Test (CCT) procedure prepared by [25] for the household energy and health

7 program, Shell Foundation is employed. This test enables to determine the amount of fuel used to

8 produce a unit amount of food (specific fuel consumption), and the total cooking time of a stove.

9 Hence, to obtain accurate data, three experienced 'Shiro wot', is a typical Ethiopian sauce prepared 10 from grains pea /chickpea/bean/ or a mixture of these with onion, oil, water, and salt, cookers were

11 selected for the test. Following the protocol, three rounds (tripled) tests were performed for each

12 stove and charcoal fuel used for this study. Accordingly, for each cooking session about $200 \mathrm{gm}$ of

13 Shiro, $150 \mathrm{ml}$ of oil, 2 liters of water, $300 \mathrm{gm}$ of onion, and $25 \mathrm{gm}$ of salt were used (as indicated in

14 Table 1 below) which is a common practice to Ethiopian households at one-time cooking of 15 wot/sauce.

16 Table 1: Type and amount of ingredients used for cooking 'woat'- Ethiopia sauce

\begin{tabular}{lllll}
\hline S.N & Ingredient & Qty & Instruction \\
\hline 1 & Mitin Shiro & $200 \mathrm{gm}$ & $\bullet$ & Fry the onion by adding a drop of water until it gets brown \\
2 & Edible oil & $150 \mathrm{ml}$ & & by adding water in a smaller portion \\
3 & Onion & $300 \mathrm{gm}$ & $\bullet$ & Then add oil and stirring randomly \\
4 & Salt & $25 \mathrm{gm}$ & $\bullet$ & Water has been added after the onion is properly cooked and \\
5 & Water & 2 liters & & left to boil \\
\hline
\end{tabular}


- The moment it starts to boil Shiro was added and the sauce was simmered for few minutes.

Note: Mitin- Shiro is a mix of some Pepper and Shiro

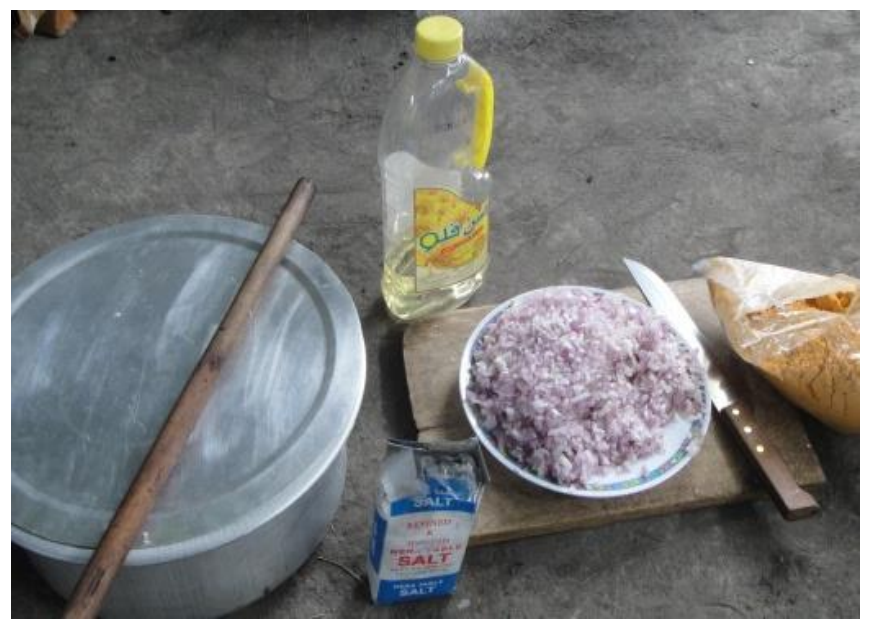

Photo9: Ingredients of 'Shiro wot'-Ethiopian sauce (by: author)

4 To collect appropriate data, before testing, three experienced women were selected as a cooker of the wot/sauce and well-oriented about the procedures of the test in such a way that both testers and

6 cookers can understand and follow each other. The role of the testers during the cooking session

7 was only to record the data and do observations without any interference to the cookers.

8 Accordingly, during each test, data related to the mass of charcoal (before, and after each test),

9 moisture of charcoal, time the stove lit (fire catches), time at which the test ends, the mass of food cooked, the mass of sauce ingredients (Shiro, onion, water, salt), air temperature, the weight of the

11 charcoal container and cooked food were recorded and entered to a spreadsheet for calculation.

\section{Cooking pot and charcoal fuel}

13 For all the tests uniform cooking pots have been used. The size of the pot used was $25 \mathrm{~cm}$ in 14 diameter. 350-400 kg of charcoal fuel of three different species was supplied for each test. The 15 three types of charcoal used during testing were named Syzygium guineense, Allophyslus 
1 abyssinicus, and Olea capensis which were collected from the Adola Woyu district of the Oromia

2 region. Before proceeding with cooking, the moisture content of charcoal samples was analyzed

3 using an oven heater and their average moisture contents range from 7.5 to $12.0 \%$. Match and

4 kerosene were used for lighting, and paper and wood sticks were used for starting the fire. After

5 each test, the remaining charcoal was weighed.

\section{Efficiency calculation}

7 In this study, the calculation of cookstove's efficiency was done following the formula of [25].

8 Accordingly, the specific fuel consumption (SFC) which is the principal indicator of stove

9 efficiency and measures the amount of wood used per $\mathrm{kg}$ of food is calculated as:

$$
S F C=\frac{f_{d}}{W_{f}} * 1000
$$

11 Where SFC is specific Fuel consumption, $\mathrm{f}_{\mathrm{d}}$ is Equivalent Dry Wood consumed and $\mathrm{W}_{\mathrm{f}}$ is the total

12 weight of cooked food. The number 1000 is a conversion factor for grams of fuel per $\mathrm{kg}$ of food 13 cooked.

14 The variables $\mathbf{f}_{\mathbf{d}}$ and $\mathbf{W}_{\mathbf{f}}$ are computed as;

$$
W_{f}=\sum_{i=1}^{2}\left(P j_{f}-p j\right)
$$

$$
\mathrm{f}_{\mathrm{d}}=\left(\mathrm{f}_{\mathrm{f}}-\mathrm{f}_{\mathrm{i}}\right) *(1-(1.12 * \mathrm{~m}))-1.5 \Delta \mathrm{c}_{\mathrm{c}}
$$
equation 3

17 Where $\mathbf{j}$ is an index for cooking pot ranging from $1-2, \mathbf{P j}$ is the weight of each pot with cooked food, $\mathbf{f}_{\mathbf{f}}$ is the final weight of fuelwood in grams (wet basis), $\mathbf{f}_{\mathbf{i}}$ is the final weight of fuelwood in grams(wet basis), $\mathbf{c}_{\mathbf{c}}$ is weight $\mathrm{o}$ charcoal container and $\mathbf{m}$ is wood moisture content (percentage 20 wet basis).

21 For calculating charcoal fuel saving of the stoves, the following formula was used: 
2 Where: $X_{\text {reduction }}=$ charcoal fuel saving; $X_{t s}=i$ s specific charcoal consumption of traditional stoves;

$3 \quad \mathrm{X}_{\text {is }}=$ specific charcoal consumption of improved charcoal stoves

\section{$4 \quad$ Emission test}

5 For testing Emission from the stoves, an emission testing hood was employed. Accordingly, the

6 charcoal stoves were placed in the hood, and then the flue test analyzer probe was inserted into the

7 hood through the sensor inlet pore to detect the $\mathrm{CO}, \mathrm{CO}_{2}, \mathrm{NO}, \mathrm{NO}$, etc. The tester logs the data

8 automatically at specific intervals. For these tests, the data was logged in 5minutes intervals. The

9 analyzer has an accuracy of $\pm 20 \mathrm{ppm} \mathrm{CO}$ with a measuring range $(0-4000 \mathrm{ppm} \mathrm{CO})$ and $1 \mathrm{ppm}$

10 resolution. The reaction time for the analyzer is approximately $40 \mathrm{sec}$. After data related to $\mathrm{CO}_{2}$,

$11 \mathrm{CO}, \mathrm{NO}, \mathrm{NO}_{\mathrm{x}}$ has been collected, since their global warming potential is different, the $\mathrm{CO}_{2} \mathrm{e}$ of

12 each greenhouse gas was calculated as follows:

$$
\mathrm{CO}_{2} \mathrm{e}=\mathrm{GWPi} * \mathrm{GHGi}
$$
Equation5

14 Where: GWPi is the global warming potential of each gas (relative to CO2), and GHGi is the 15 quantity of each greenhouse gas emitted.

16 Finally, for calculating the greenhouse gas emission reduction potentials of each improved

17 charcoal stove under investigation relative to the traditional metal stoves the following equation 18 was employed.

$$
\text { Yreduction }=\frac{Y t s-Y i s}{Y t s} * 100
$$
equation 6

20 Where, $\mathrm{Y}_{\text {reduction }}=$ denotes reduction of $\mathrm{CO}_{2}, \mathrm{CO}, \mathrm{NO}_{\mathrm{x}}, \mathrm{NO}$ emission, $\mathrm{Yts}=$ is $\mathrm{CO} 2, \mathrm{CO}, \mathrm{NOx}$,

$21 \mathrm{NO}$; $\mathrm{Y}$ is = is $\mathrm{CO} 2, \mathrm{CO}, \mathrm{NOx}, \mathrm{NO}$ and/or specific charcoal consumption of improved stoves; 


\section{Data Analysis}

2 The data analysis was made using statistical package for social science (SPSS) version 20, and

3 Microsoft excel. Accordingly, the statistical differences in emission of $\mathrm{CO} 2, \mathrm{CO}, \mathrm{NOx}$, and $\mathrm{NO}$

4 and specific charcoal fuel consumption were computed using multivariate analysis and analysis of

5 variance at a 5\% significance level. Other descriptive statistics like percentage, mean and standard

6 deviation were also calculated for quantitative data. Finally, tables, figures, and pie charts were

7 used for summarizing and displaying the findings.

\section{Result and Discussion}

\section{Charcoal Cookstove preference of households}

The overall result indicates that the majority of the respondents $(62.69 \%)$ prefer to use locally

11 manufactured improved charcoal stoves compared to the traditional metal charcoal stoves

$12(37.31 \%)$ for various household cooking activities (figure 3 below). As reiterated by respondents,

13 this charcoal stove is comparatively durable and causes fewer impacts like hand burning, less heat

14 loss, and is comparatively efficient compared to traditional stoves which are characterized by less

15 durability, cause hand burning, and heat transmittance (loss). When we compare each improved

16 stove with a traditional metal stove, most of the respondent households $(37.31 \%)$ use a traditional

17 metal stove. The possible reasons for reliance on this stove were its affordability (less cost),

18 availability, and absence of other improved charcoal stoves in the market. Following traditional

19 metal stoves, Lakech (29.36\%), Mirchaye (13.46\%), and Kib (11.01\%) are widely used whereas

20 Obama charcoal stoves are the least preferred stove $(8.87 \%)$. The adoption of the aforementioned

21 charcoal stoves was limited by several interacting factors including stoves availability,

22 affordability, awareness, distance to market, and absence of producers and distributer. The same

23 finding was reported by [18], and [26] Kooser (2014) which state that most of the communities in 
1 Ethiopia were not yet adopted appropriate charcoal stoves due to lack of availability in the market

2 and distance to the market. During focus group discussion, the respondents were also stressed that

3 all the above-mentioned charcoal stoves are not produced in their surrounding area rather obtained

4 from other large cities like Addis Ababa, Awassa, and Shashemane. On top of this, they stated that

5 the stoves available in the market also varied in shape, size and durability and majority of them

$6 \quad$ were not produced as per the stove standard.

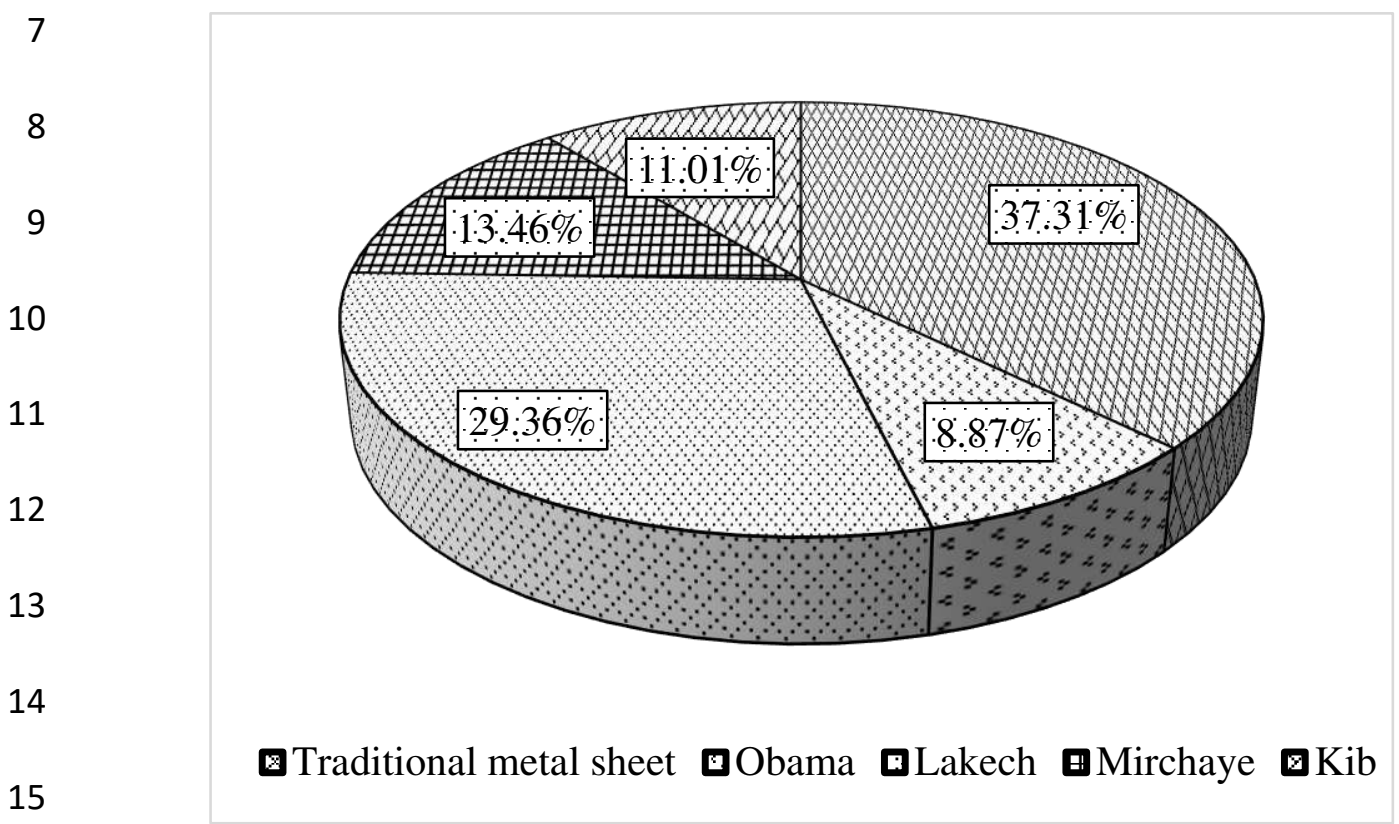

16

$17 \quad$ Figure 1: The commonly used charcoal stoves by local communities across the study area

18 The result of household survey analysis also showed that major (65\%) respondents use charcoal as a source of energy for household cooking like cooking 'woat', boiling coffee, and house heating.

20 However, the amount of consumption varies between different household activity which is also in

21 line with the finding of [27], [28] and [29]. The respondents mentioned that they obtained charcoal

22 fuel from different sources. Among the total users of charcoal, about $45 \%$ produce charcoal for

23 their household consumption whereas the remaining $20 \%$ obtain it through purchasing from the

24 local market. Based on their indigenous knowledge, the respondents use the duration of charcoal 
1 burning, ash, and smoke formation; and availability as criteria for selecting plant species used for

2 charcoal making and while purchasing from the market[30], [31]. Accordingly, in the study area,

3 Syzygium guineense, Olea capensis, and Allophyslus abyssinicus were the top three plant species

4 used for charcoal production and charcoal types to be purchased from the market (Table 2). The

5 finding of [27], and [31] also affirmed that these plants are commonly used for charcoal making

6 in the Gurage zone and around Awash national park of Ethiopia.

7 Table 2: Plant Species preference for charcoal production in the study area

\begin{tabular}{|c|c|c|c|c|c|c|c|}
\hline \multirow{3}{*}{ Scientific Name } & \multirow{3}{*}{ Local Name } & \multicolumn{4}{|c|}{ Rank } & \multirow{3}{*}{ Total } & \multirow{3}{*}{ Rank } \\
\hline & & & & & & & \\
\hline & & 1 & 2 & 3 & 4 & & \\
\hline Celtis africana & Mataqoma & 11 & 15 & 2 & 0 & 28 & 4 \\
\hline Syzygium guineense & Badessa & 80 & 37 & 16 & 2 & 135 & 1 \\
\hline Allophyslus abyssinicus & Sarajii & 5 & 20 & 12 & 2 & 39 & 3 \\
\hline Landolphia buchananii & Hope & 4 & 2 & 4 & 0 & 10 & 8 \\
\hline Olea capensis & Gagamaa & 54 & 41 & 12 & 1 & 108 & 2 \\
\hline Acacia abyssinica & Girar & 1 & 0 & 0 & 0 & 1 & 9 \\
\hline Prunus africana & Sukkee & 2 & 5 & 2 & 1 & 10 & 8 \\
\hline Teclea simplicifolia & Hadhessa & 8 & 5 & 2 & 0 & 15 & 6 \\
\hline Ocotea kenyensis & Daressa & 2 & 7 & 9 & 0 & 18 & 5 \\
\hline Rhus glutinosa & Tatessa & 0 & 1 & 0 & 0 & 1 & 9 \\
\hline Psydrax schimperiana & Golelo & 0 & 8 & 5 & 1 & 14 & 7 \\
\hline
\end{tabular}




\section{Equivalent dry charcoal consumption}

3 The overall result of this study showed that the highest mean charcoal fuel consumption $(0.288 \mathrm{~kg})$

4 was recorded by traditional metal charcoal stove followed by 'Kib' stove $(0.201 \mathrm{Kg})$ and

5 'Mirchaye' stove $(0.192 \mathrm{~kg})$. Among the four stoves under investigation, the lowest overall

6 charcoal consumption was recorded by the Lakech stove $(0.188 \mathrm{~kg})$. As indicated in Figures 5 and

76 below, the amount of charcoal fuel consumed by each stove was also different from one plant

8 species to another plant species from which charcoal has been produced. Similarly, though it is not

9 statistically significant $(\mathrm{P}>0.997)$, the result of one-way analysis of variance (ANOVA) and the

10 mean plots (figure 5) showed that there is a difference in the amount of equivalent dry charcoal

11 fuel consumption which is produced from different plant species.

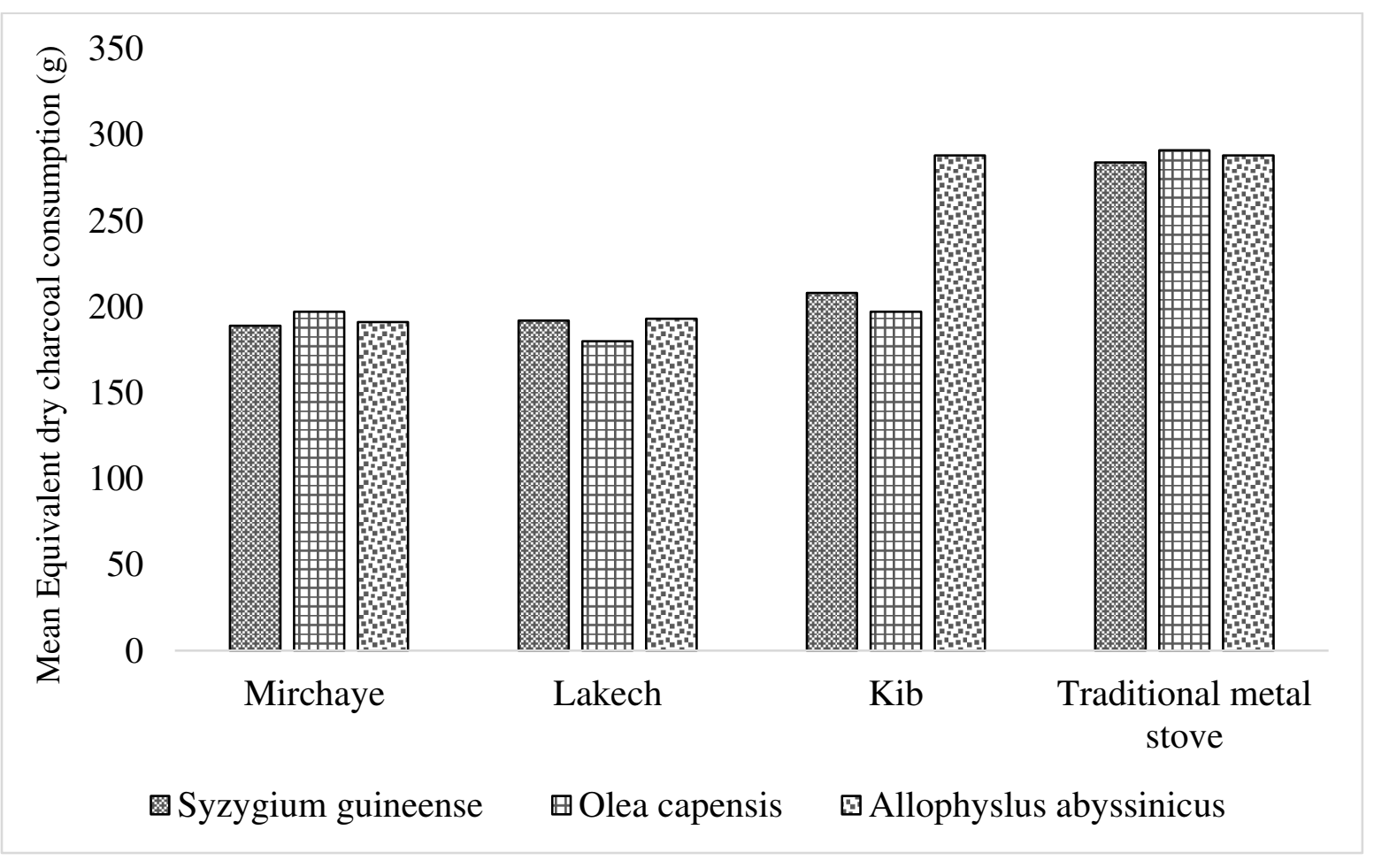

13 Figure 2: Average equivalent dry charcoal consumption of different stove types 


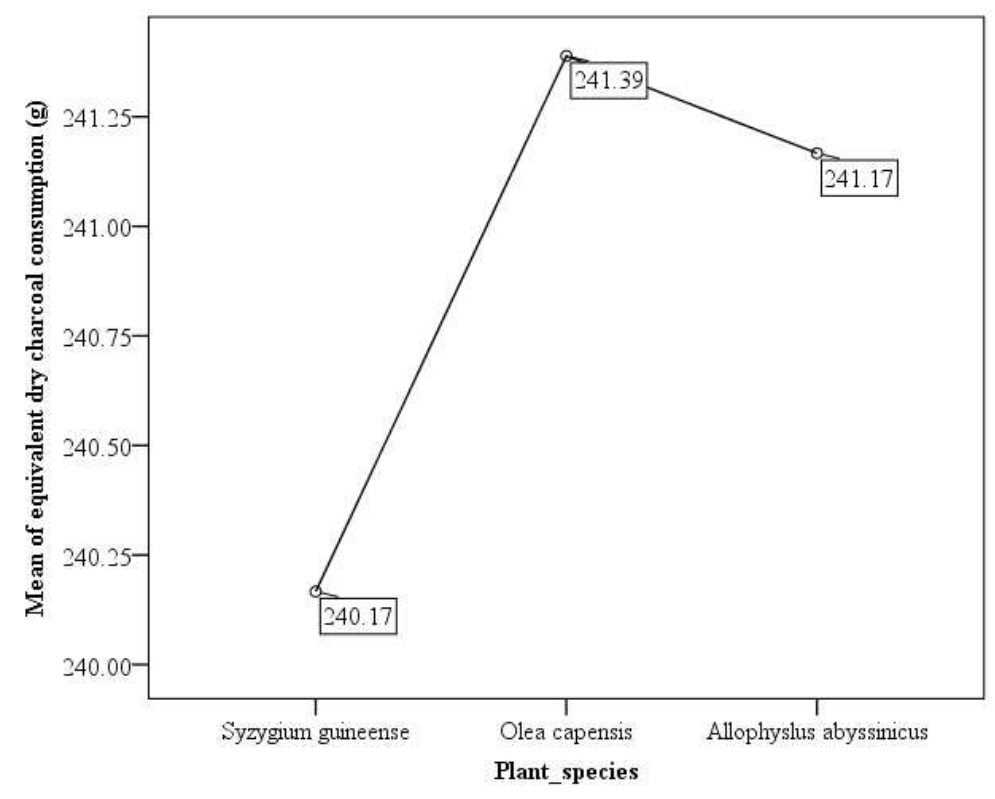

1

$2 \quad$ Figure 3: Mean plot of plant species wise equivalent dry charcoal fuel consumption

3 Charcoal Fuel Saving by stoves

4 The overall result of the analysis affirmed that the stoves used by the respondents contributed to

$5 \quad 32.33 \%$ charcoal fuel-saving relative to traditional metal stoves as indicated in Table 3 below. This

6 implies that using locally produced charcoal stoves under investigation instead of traditional metal

7 stoves would enable the respondents to averagely save about $68.44 \mathrm{~kg}$ of charcoal fuel per year. In

8 other words, if the local communities use these improved stoves than traditional stoves about

90.0015 ha of the forest would be saved from conversion to charcoal for energy sources. This would

10 be about 0.49 ha if multiplied with all respondents (327) used for data collection is considered in

11 the calculation. The studies [16], [32], [33] were also showed that improved charcoal stoves have

12 to potential to reduce deforestation. As indicated in table 3, there is also a significant difference in

13 mean charcoal fuel-saving potentials among the three stoves (Mirchaye, Lakech, and Kib stove)

14 relative to the traditional metal stoves. The result of the analysis of variance also showed that there

15 is a significant $(\mathrm{P}=0.000)$ mean difference in fuel consumption among the stoves (table 5). 
1 Accordingly, the Lakech charcoal stove recorded the highest (34.56\%) fuel-saving potential

2 followed by the Mirchaye stove (33.27\%). This implies that Lakech and Mirchaye stoves save

3 about $72.60 \mathrm{Kg}$ and $69.68 \mathrm{Kg}$ of charcoal fuels which are equivalent to 0.0016 and $0.0003 \mathrm{ha}$ of

4 forest per year, respectively.

5 Table 3: charcoal fuel saving by different stoves used during the controlled cooking test

\begin{tabular}{lcccc}
\hline Types of stoves & Mean (g) & SD & Charcoal saved (g) & \% Char saved \\
\hline Traditional metal stove (baseline) & 287.78 & 5.41 & & \\
Mirchaye stove & 192.33 & 4.50 & 95.45 & 33.17 \\
Lakech stove & 188.33 & 6.80 & 99.45 & 34.56 \\
Kib stove & 201.44 & 9.10 & 86.34 & 30.00 \\
\hline Mean total & 869.88 & & 281.24 & 32.33 \\
& & & 187.50 &
\end{tabular}

6 *The average number of sauce cooking per day is 2 ; the mean charcoal saved was $93.75 \mathrm{~g}$

$7 \quad$ Specific Fuel Consumption

8 The overall result of analysis of variance and descriptive statistics showed that there was a 9 significant difference $(\mathrm{p}<0.000)$ in specific charcoal fuel consumption among the stove types under investigation (as indicated in Table 6 and Table 5 respectively). The traditional metal stove 11 consumes about $125.22 \pm 4.10 \mathrm{~g}$ of charcoal fuel for one time wot/sauce cooking session, which is 12 much higher compared to other charcoal stoves. In other words, about $250.22 \mathrm{~g}$ of charcoal is 13 required per day for a household using a traditional charcoal stove. This is by far smaller than the 14 findings of [18] which states that the traditional stoves commonly used in the Adaba district of the 15 Oromia region states consume about $700 \mathrm{~g}$ charcoal per year. This implies that the traditional metal 16 stoves in the study area perform well in terms of fuel-saving compared to the traditional stoves 
1 reported in Adaba district. Among all stoves, Mirchaye consumes fewer $(83.22 \pm 2.44)$ fuels

2 followed by the Lakech stove $(85.22 \pm 1.86)$ and Kib stove $(87.67 \pm 3.97)$. The highest specific

3 fuel consumption of a traditional charcoal stove is attributed due to the material from which it was

4 constructed and heat loss [18], [34], [35].

5 More interestingly, the specific charcoal fuel consumption of the stoves under investigation also

6 differs based on types of charcoal fuels which is related to the types of wood plants used to produce

7 the fuel as indicated in Figure 5 below. Accordingly, traditional stoves consume more charcoals

8 fuel produced from Syzygium guineense ( $129 \mathrm{~g}$ ) followed by Olea capensis (126g) and Allophylus

9 abyssinicus (121g) per cooking session. The possible contributing factors for higher consumption

10 of Syzygium guineense might be due to its lower heating/calorific value relative to other charcoal

11 fuels like Olea capensis $(7262.3 \mathrm{cal} / \mathrm{g})$ and Allophylus abyssinicus $(6728 \mathrm{cal} / \mathrm{g})$ as indicated in

12 Table 4 below. The other possible reason might be its higher ash content (7\%).

13 Based on types of charcoal (wood plant species used for had been produced), there is also a 14 difference in the quantity of fuels consumed by locally manufactured improved charcoal stoves

15 (Figure 6). Accordingly, Mirchaye stove consumes less amount of Allophylus abyssinicus based 16 charcoal whereas relatively higher amount of Syzygium guineense followed by Olea capensis. Kib

17 stove consumes relatively higher Allophylus abyssinicus based charcoal whereas relatively similar

18 for other fuels. Similarly, even though there is a slight difference, the Lakech stove consumes a 19 relatively equal amount of charcoal regardless of wood species. The possible reason for variation 20 might be associated with moisture content and the amount of air (oxygen) that participated in the 21 combustions of the charcoal fuels (Table 4). This is in agreement with the finding of [35] which 22 states that fuel types and design of stoves have an impact on specific fuel consumption potentials 23 of improved cookstoves. 


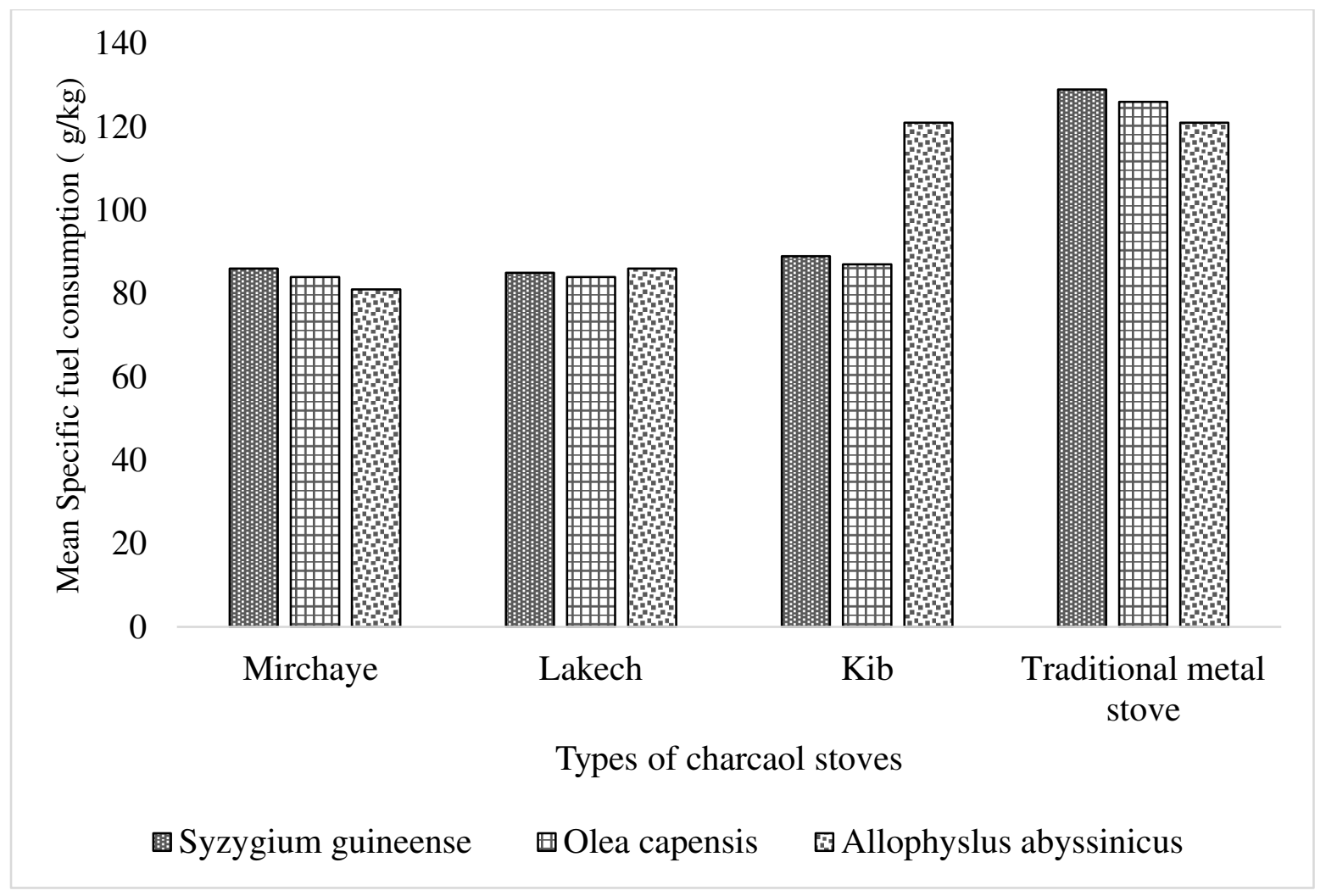

2 Figure 4: Specific fuel consumption of different stoves relative to the traditional charcoal stove

3 Table 4: proximate analysis and calorific value of plant species used as charcoal fuels

\begin{tabular}{lccccc}
\hline Sample type & \%MC & \%VM & \% AC & \%FC & CV (Cal/g) \\
\hline Olea capensis & 8 & 14 & 1 & 79.5 & 7262.3 \\
Allophylus abyssinicus & 12 & 8.5 & 3.5 & 76 & 6728 \\
Syzygium guineense & 7.5 & 12 & 7 & 71 & 6209.9
\end{tabular}

4 MC: Moisture content; $\mathrm{VM}=$ Volatile matter; $\mathrm{AC}=\mathrm{Ash}$ content $\mathrm{FC}=$ Fixed carbon; $\mathrm{CV}=\mathrm{Calorific}$ 5 value

\section{Total Cooking Time}

7 The overall result of the study shows that cooking time varies from stove to stove. Accordingly, 8 the highest $(68.22 \pm 6.39 \mathrm{~min})$ cooking time was recorded by traditional metal charcoal stove 
1 whereas the lowest cooking time $(38.44 \pm 2.13 \mathrm{~min})$ was by Mirchaye stove. Among the stoves

2 under investigation, compared to the traditional charcoal stoves, the Mirchaye stove performs very

3 well in terms of fuel consumption and reducing cooking time. This finding is by far (almost

4 twofold) lower than the finding [18] which stated that the Mirchaye stove took 220 minutes for

5 cooking per day. In the present research finding, surprisingly, it is not only the Mirchaye stove that

6 performed better in terms of saving time and fuels, Lakech and Kib stoves were also saving more

7 time relative to the fining of [18]. The difference might be due to the quality of material from

8 which they constructed, the design of stove and wood plants used as fuel sources (charcoal).

9 From the finding, in addition to saving fuels and contributing to reducing forest degradation, the

10 Mirchaye stove also has the potentials to save the time of the households that uses improved 11 cookstove technology by $43.65 \%$ compared to traditional stoves. Besides Mirchaye stove, Kib and 12 Lakech stoves also can save the time of household users by $31.43 \%$ and $29.08 \%$ respectively. Even 13 though the stoves under investigation weren't produced as per the standard and weren't accredited 14 by the Measurement and Standardization Agency of the county, they demonstrated the highest 15 performance compared to the findings that have been reported by different authors [16], [18], and 16 [35]. This implies that higher time and fuel-saving potentials of locally produced improved stoves 17 have a great contribution for allowing the community to have more time to participate in different 18 socio-economic activities like agriculture, education, etc. Several research findings pinpointed this 19 as improved stove have multidimensional function like providing more time for children and 20 women to participate in education [36], [37], reducing working load, enhancing health benefits 21 [24], reducing the emission of indoor air pollutants [38]-[40], and reducing the impact on forest 22 resources [11], [41], [42]. 


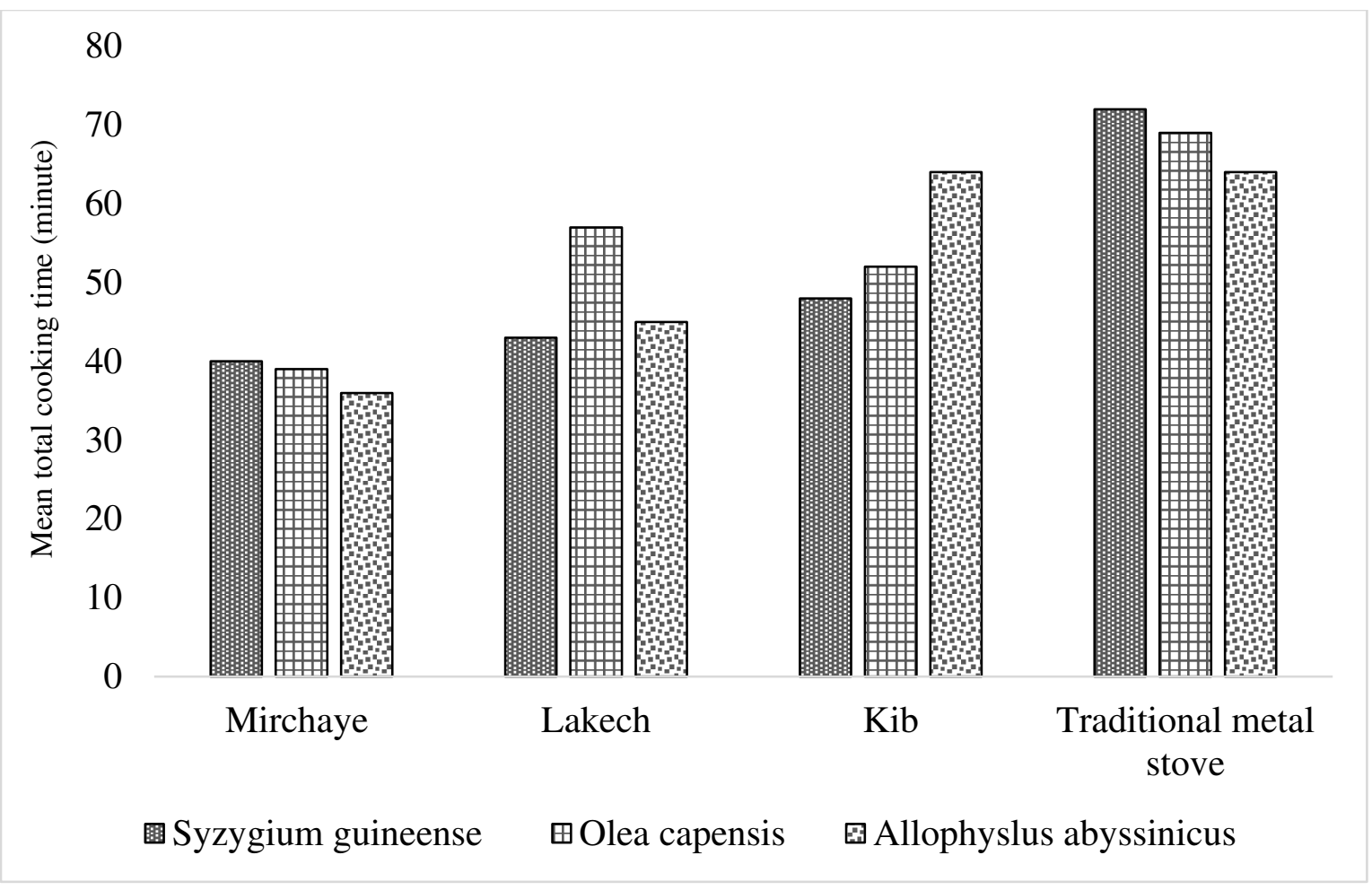

2 Figure 5: Mean total cooking time (in minutes) elapsed by different charcoal stoves under

3 investigation

4 Table 5: The result of analysis of variance of the total weight of cooked food, equivalent dry

5 charcoal consumed, specific fuel consumption, and total cooking time

\begin{tabular}{llccccc}
\hline & & Sum of Squares & df & Mean Square & F & Sig. \\
\hline \multirow{2}{*}{ TWCF } & Between Groups & 60172.815 & 3 & 20057.605 & 4.500 & .007 \\
& Within Groups & 222864.444 & 50 & 4457.289 & & \\
& Total & 283037.259 & 53 & & & \\
& Between Groups & 119441.648 & 3 & 39813.883 & 1018.316 & .000 \\
EDCC & Within Groups & 1954.889 & 50 & 39.098 & & \\
& Total & 121396.537 & 53 & & & \\
& Between Groups & 21529.481 & 3 & 7176.494 & 562.617 & .000
\end{tabular}




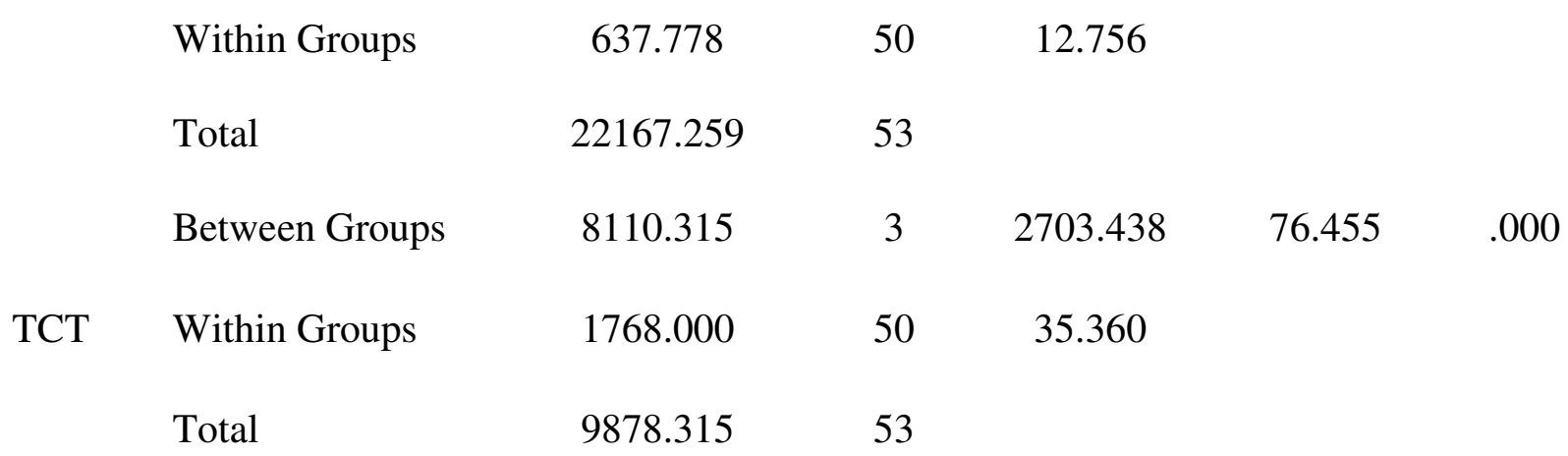

1 Significance level at alpha $=5 \%$ TWCF $=$ total wight of cooked food EDCC $=$ equivalent dry

2 charcoal consumption; $\mathrm{SFC}=$ Specific Fuel Consumption; TCT $=$ Total Cooking Time

3 Table 6: The result of overall descriptive statistics of TWCF, EDCC, SFC, and TCT

\begin{tabular}{|c|c|c|c|c|c|c|}
\hline & & Mean & Std. & Std. & $95 \% \mathrm{CIf}$ & or Mean \\
\hline & & & Deviation & Error & Lower Bound & Upper Bound \\
\hline & Traditional metal stove & 2297.44 & 72.74 & 13.99 & 2268.67 & 2326.22 \\
\hline & Mirchaye & 2309.44 & 75.68 & 25.22 & 2251.27 & 2367.62 \\
\hline TWCF & Lakech & 2211.67 & 58.97 & 19.65 & 2166.34 & 2256.99 \\
\hline & Kib & 2300.78 & 38.18 & 12.72 & 2271.43 & 2330.12 \\
\hline & Total & 2285.70 & 73.08 & 9.94 & 2265.76 & 2305.65 \\
\hline & Traditional metal stove & 287.78 & 5.41 & 1.04 & 285.64 & 289.92 \\
\hline & Mirchaye & 192.33 & 4.50 & 1.50 & 188.87 & 195.79 \\
\hline EDCC & Lakech & 188.33 & 6.80 & 2.26 & 183.11 & 193.56 \\
\hline & Kib & 201.44 & 9.10 & 3.03 & 194.45 & 208.44 \\
\hline & Total & 240.91 & 47.86 & 6.51 & 227.84 & 253.97 \\
\hline & Traditional metal stove & 125.22 & 4.10 & .79 & 123.60 & 126.84 \\
\hline & Mirchaye & 83.22 & 2.44 & .81 & 81.35 & 85.10 \\
\hline
\end{tabular}




\begin{tabular}{|c|c|c|c|c|c|c|}
\hline & Lakech & 85.22 & 1.86 & .62 & 83.80 & 86.65 \\
\hline & Kib & 87.67 & 3.97 & 1.32 & 84.62 & 90.72 \\
\hline & Total & 105.30 & 20.45 & 2.78 & 99.71 & 110.88 \\
\hline & Traditional metal stove & 68.22 & 6.39 & 1.23 & 65.70 & 70.75 \\
\hline & Mirchaye & 38.44 & 2.13 & .71 & 36.81 & 40.080 \\
\hline TCT & Lakech & 48.22 & 6.51 & 2.17 & 43.21 & 53.23 \\
\hline & Kib & 46.78 & 6.44 & 2.15 & 41.83 & 51.73 \\
\hline & Total & 56.35 & 13.65 & 1.86 & 52.63 & 60.08 \\
\hline
\end{tabular}

1

2 Total Emission Evaluation for charcoal stoves

3 The result of laboratory analysis affirmed that the mean emission of pollutants (carbon dioxide,

4 carbon monoxide, NOx, and nitrogen monoxide) was varying from stove to stove. The Pillai's

5 trace (partial Eta squared) value showed that about $66.8 \%$ of the variation in pollutants emitted by

6 stoves are associated with the types of plant species used as charcoal fuel whereas the stove types

7 are the second (34.4\%) contributor (Table 7).

8 Carbon dioxide (CO2): The result of multivariate analysis (Table 7 below) also showed that there

9 was a statistically significant $(\mathrm{P}=0.000)$ mean difference in mean carbon dioxide emission from

10 stoves under investigation. The highest (18\%) percentage of variation (differences) in the amount

11 of carbon dioxide emission was attributed due to the types of stoves used by households (Table 8).

12 Accordingly, as indicated in figure 8 below, traditional charcoal stoves emit a significantly higher

13 amount of carbon dioxide as compared to improved stoves considered for this particular study.

14 This implies that improved stoves have the potential to reduce household air pollution and other

15 health problems associated with traditional biomass consumption as sources of energy [24], [43]. 
1 The finding of [4], [44] also showed that switching to more efficient improved cooking stoves has

2 the potential to reduce emissions that can also contribute to reducing acute respiratory infection,

3 lung cancer and eye irritations.

4 The percentage emission reduction analysis result showed that among improved stoves, the kib

5 charcoal stove emits lower amounts $(11,496.67 \mathrm{ppm})$ of carbon dioxide as compared to other

6 charcoal stoves. On the contrary, the traditional charcoal stove relatively emits a very high amount

7 of carbon monoxide. In other words, among locally produced improved stoves under

8 consideration, the kib stove has a higher potential (83.12\%) to reduced carbon dioxide emission

9 followed by Lakech and Mirchaye stoves (Table 9).

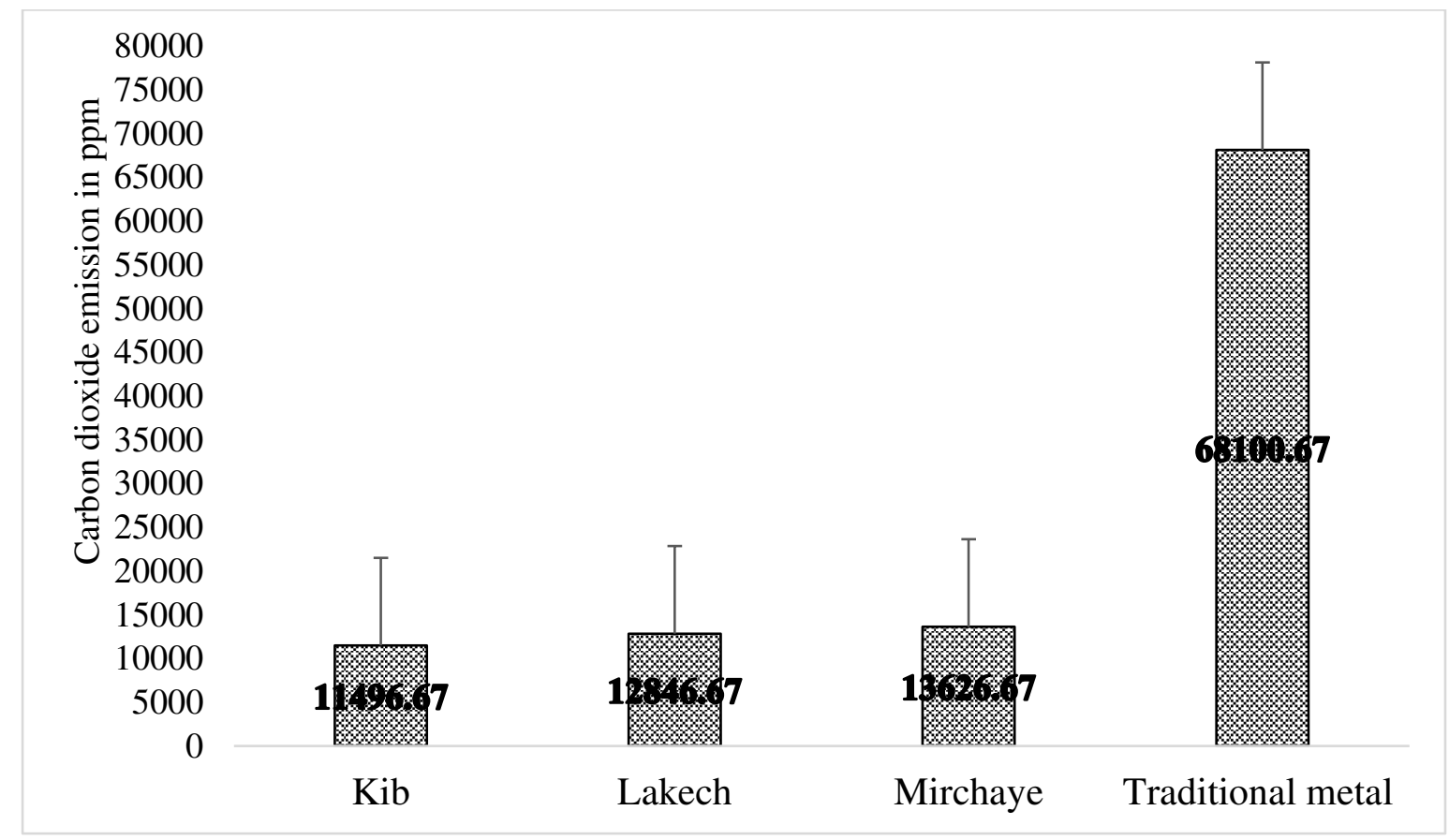

11 Figure 6: The mean carbon dioxide emission of different types of charcoal stoves

12 Carbon monoxide (CO): The multivariate analysis result reveals that there is a significant mean 13 difference $(\mathrm{P}<0.05)$ in carbon monoxide emission by different charcoal stoves that are used by 14 local communities in the study area. The value of partial Eta squared also indicates that the highest 
$1(80.2 \%$ and $68 \%)$ percentage share of the variation in the amount of carbon monoxide emission

2 was attributed due to the interactive effect of stove types and wood plant species used for making

3 charcoal respectively (Table 8). The stove types also contribute to a difference in the emission of

4 carbon monoxide difference even though its percent share is lower (10.9\%) compared to what has

5 been mentioned. Accordingly, as indicated in figure 9 below, the traditional metal charcoal stove

6 emits significantly much higher amount of carbon monoxide relative to other charcoal stoves under

7 consideration. This is in line with the findings of [18], [45]. However, in terms of the magnitude

8 of emission, the traditional stove of this particular study emits a significantly higher amount of

9 pollutants compared to findings of [45] which were about 4,526 ppm per annum and also that of

10 [23], [46]. Whereas the mean difference of Lakech stove with other charcoal stoves showed that

11 Lakech emits about $-7,824.37,-62.34$ and -127.37 ppm less as to traditional metal, Kib and

12 Mirchaye stoves respectively. In other words, in terms of their emission of carbon monoxide,

13 Lakech stove $<$ Kib stove $<$ Mirchaye stove $<$ traditional metal charcoal stove as indicated in figure

149 below. This means that relative to traditional charcoal stoves, Lakech stoves have the highest

15 potential to reduce the emission of carbon monoxide per household's cooking activity. Kib and

16 Mirchaye also have the highest carbon monoxide emission reduction capacity as compared to

17 traditional stoves. Furthermore, they have a great contribution in reducing indoor air pollution and

18 other health-related problems with exposure to carbon monoxide. 


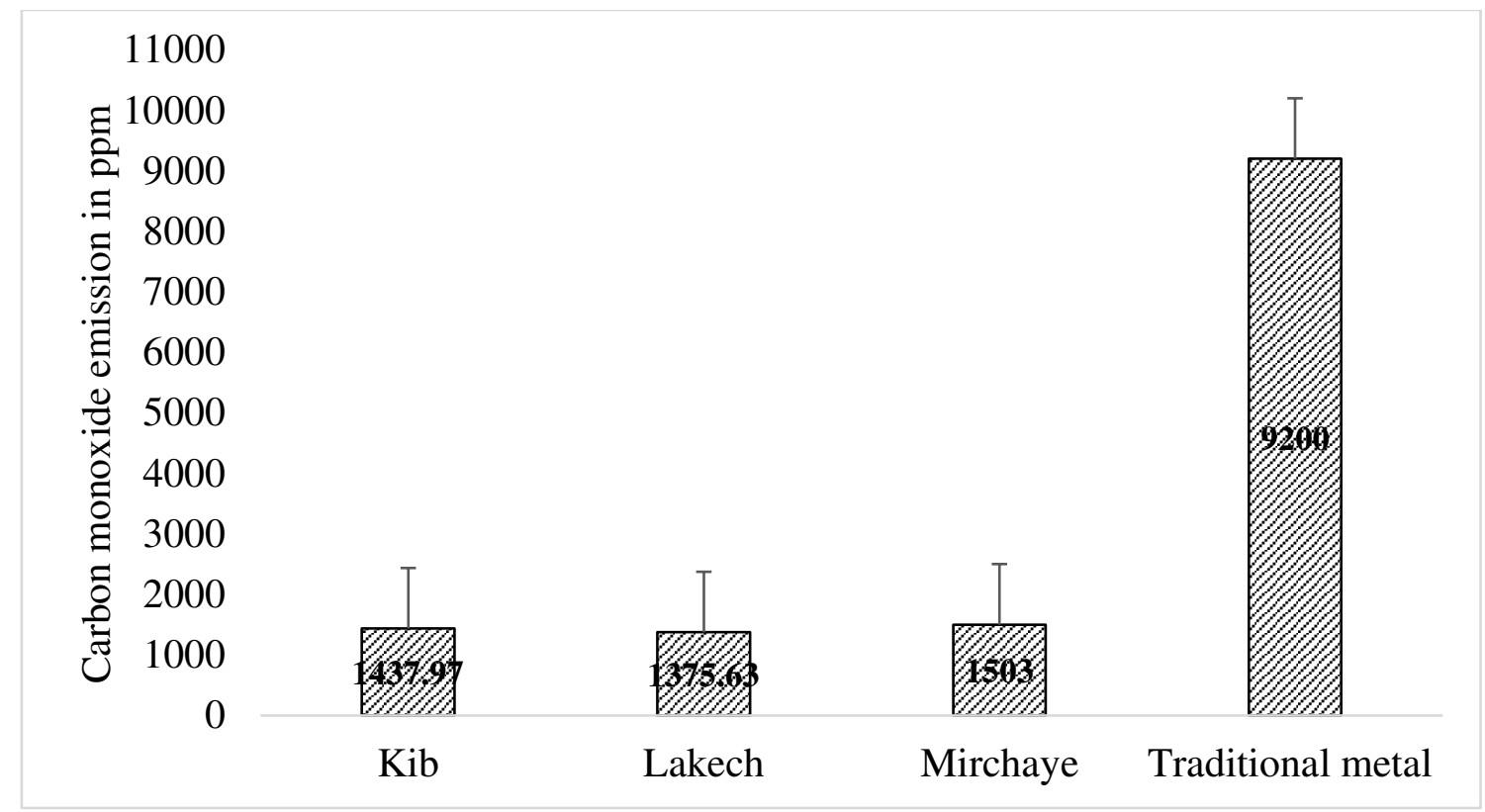

$2 \quad$ Figure 7: The mean emission of carbon monoxide from different charcoal stoves

3 Nitrogen oxides (NOx): The amount of NOx emission is also differing among the charcoal stoves.

4 The value of partial Eta squared showed that about $43.1 \%$ of the variation in nitrogen oxides

5 emission is due to the types of wood plants species used as charcoal fuel as indicated in Table 8,

6 below. Additionally, the types of charcoal stoves (32.7\%) used by itself were also contributed to

7 the difference in emission. Figure 10 below also shows that similar to carbon dioxide and carbon

8 monoxide, traditional metal charcoal emits a higher amount of NOx's followed by Mirchaye stove

9 whereas kib stove emits relatively very low. 


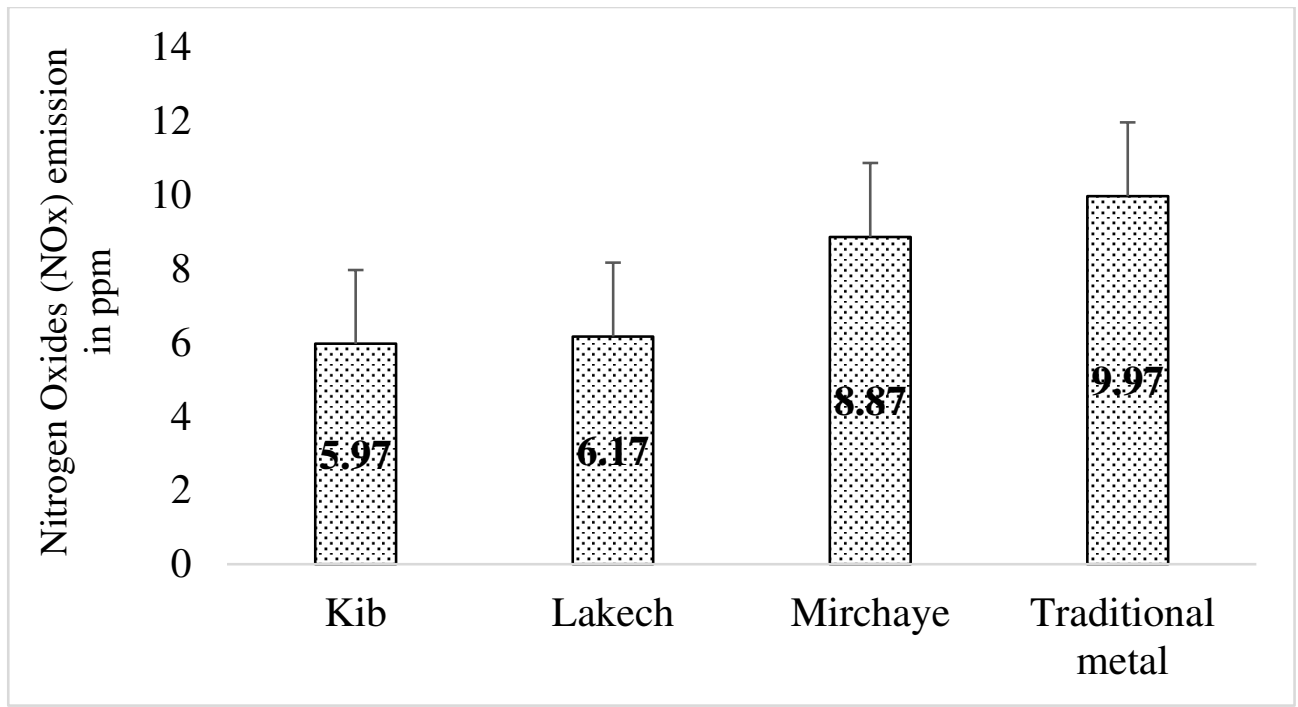

$2 \quad$ Figure 8: The mean nitrogen oxides (NOx) emissions from different charcoal stoves

3 Nitrogen Monoxide (NO): As for other pollutants, in the result of multivariate analysis_ $\mathrm{P}<0.05$,

4 the amount of nitrogen monoxide emission also varies between the charcoal stove under

5 investigation (Table 6). The partial Eta squared value of the between-subject effect analysis result

6 showed that about $45.3 \%$ of the variation in nitrogen monoxide pollutant is emitted and attributed

7 as a result of plant species used for charcoal fuel preparation. Furthermore, $33.6 \%$ of the variation

8 in NO is the result of the difference in stove types used by the respondents.

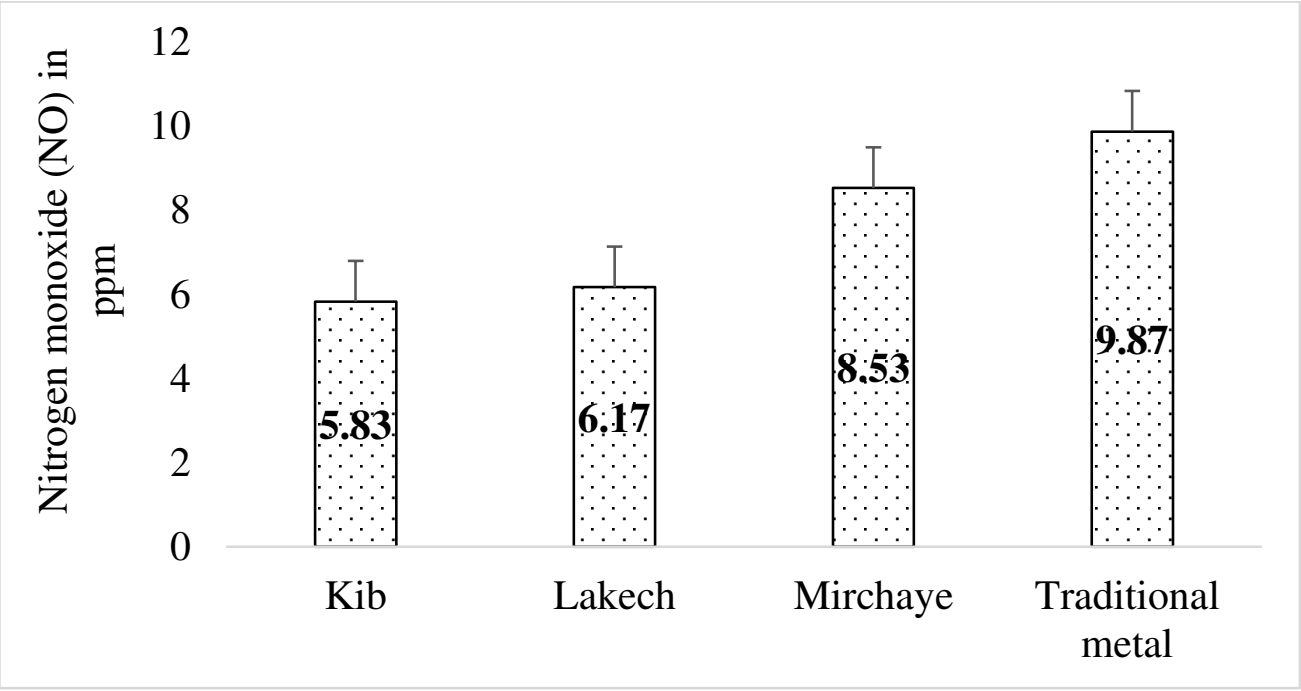

$10 \quad$ Figure 9: The mean emission of nitrogen monoxide in ppm from different charcoal stoves 
1 Table 7: The multivariate tests of emissions from different charcoal stoves and charcoal fuels

\section{Multivariate Tests ${ }^{\mathrm{a}}$}

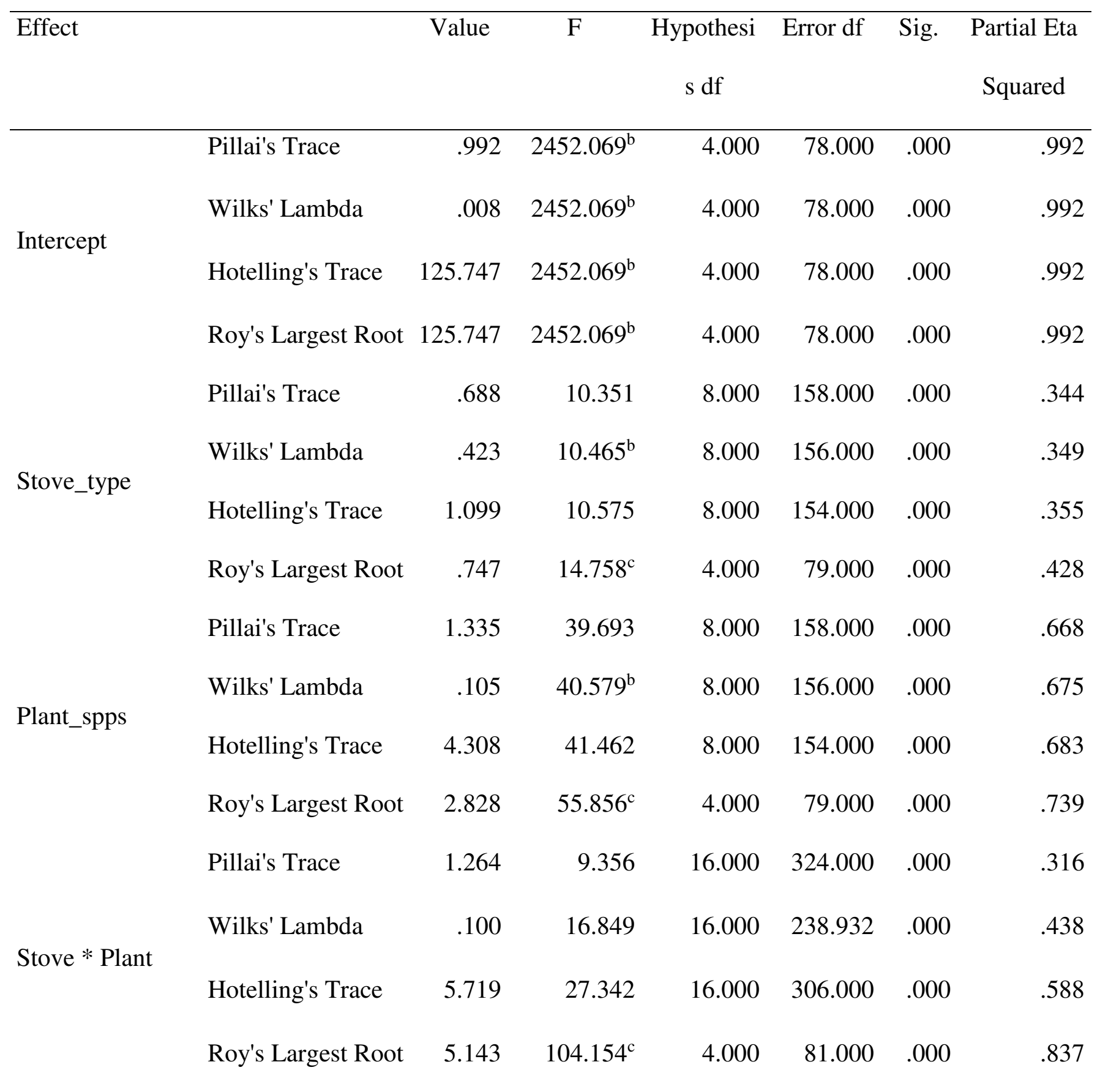

a. Design: Intercept + Stove_type + Plant_spps + Stove_type $*$ Plant_spps

b. Exact statistic 
c. The statistic is an upper bound on F that yields a lower bound on the significance level.

$1 \quad$ Table 8: The tests of between subject's effects

\begin{tabular}{|c|c|c|c|c|c|c|c|}
\hline Source & Dependent & Type III Sum & $\mathrm{df}$ & Mean Square & $\mathrm{F}$ & Sig. & Partial Eta \\
\hline & Variable & of Squares & & & & & Squared \\
\hline & $\mathrm{CO} 2$ & $120036000.00^{\mathrm{a}}$ & 8 & 15004500.00 & 3.82 & .001 & .274 \\
\hline Corrected & $\mathrm{CO}$ & $12508847.60^{\mathrm{b}}$ & 8 & 1563605.95 .0 & 63.63 & .000 & .863 \\
\hline \multirow[t]{4}{*}{ Model } & NOx & $448.60^{c}$ & 8 & 56.08 .5 & 14.05 & .000 & .581 \\
\hline & $\mathrm{NO}$ & $384.422^{\mathrm{d}}$ & 8 & 48.05 & 15.12 & .000 & .599 \\
\hline & & 14417209000.0 & & 14417209000.0 & & & \\
\hline & $\mathrm{CO} 2$ & 0 & 1 & 0 & 3669.94 & .000 & .978 \\
\hline \multirow[t]{5}{*}{ Intercept } & $\mathrm{CO}$ & 186330355.60 & 1 & 186330355.60 & 7582.23 & .000 & .989 \\
\hline & NOx & 4410.00 & 1 & 4410.00 & 1104.55 & .000 & .932 \\
\hline & $\mathrm{NO}$ & 4216.18 & 1 & 4216.18 & 326.769 & .000 & .942 \\
\hline & $\mathrm{CO} 2$ & 69678000.00 & 2 & 34839000.00 & 8.87 & .000 & .180 \\
\hline & $\mathrm{CO}$ & 243370.47 & 2 & 121685.23 & 4.95 & .009 & .109 \\
\hline \multirow{4}{*}{ Stove_type } & NOx & 157.40 & 2 & 78.70 & 19.71 & .000 & .327 \\
\hline & $\mathrm{NO}$ & 130.022 & 2 & 65.011 & 20.458 & .000 & .336 \\
\hline & $\mathrm{CO} 2$ & 18378666.67 & 2 & 9189333.33 & 2.34 & .103 & .055 \\
\hline & $\mathrm{CO}$ & 4225128.07 & 2 & 2112564.03 & 85.97 & .000 & .680 \\
\hline \multirow{3}{*}{ Plant_spps } & NOx & 245.27 & 2 & 122.63 & 30.72 & .000 & .431 \\
\hline & $\mathrm{NO}$ & 213.09 & 2 & 106.54 & 33.53 & .000 & .453 \\
\hline & $\mathrm{CO} 2$ & 31979333.33 & 4 & 7994833.33 & 2.04 & .097 & .091 \\
\hline Stove * Plant & $\mathrm{CO}$ & 8040349.07 & 4 & 2010087.27 & 81.80 & .000 & .802 \\
\hline
\end{tabular}




$\begin{array}{lllllll}\text { NOx } & 45.93 & 4 & 11.48 & 2.88 & .028 & .124 \\ \text { NO } & 41.31 & 4 & 10.33 & 3.25 & .016 & .138\end{array}$

a. R Squared $=.274($ Adjusted R Squared $=.202)$

b. R Squared $=.863$ (Adjusted R Squared $=.849)$

c. R Squared $=.581($ Adjusted R Squared $=.540)$

d. R Squared $=.599($ Adjusted R Squared $=.559)$

1

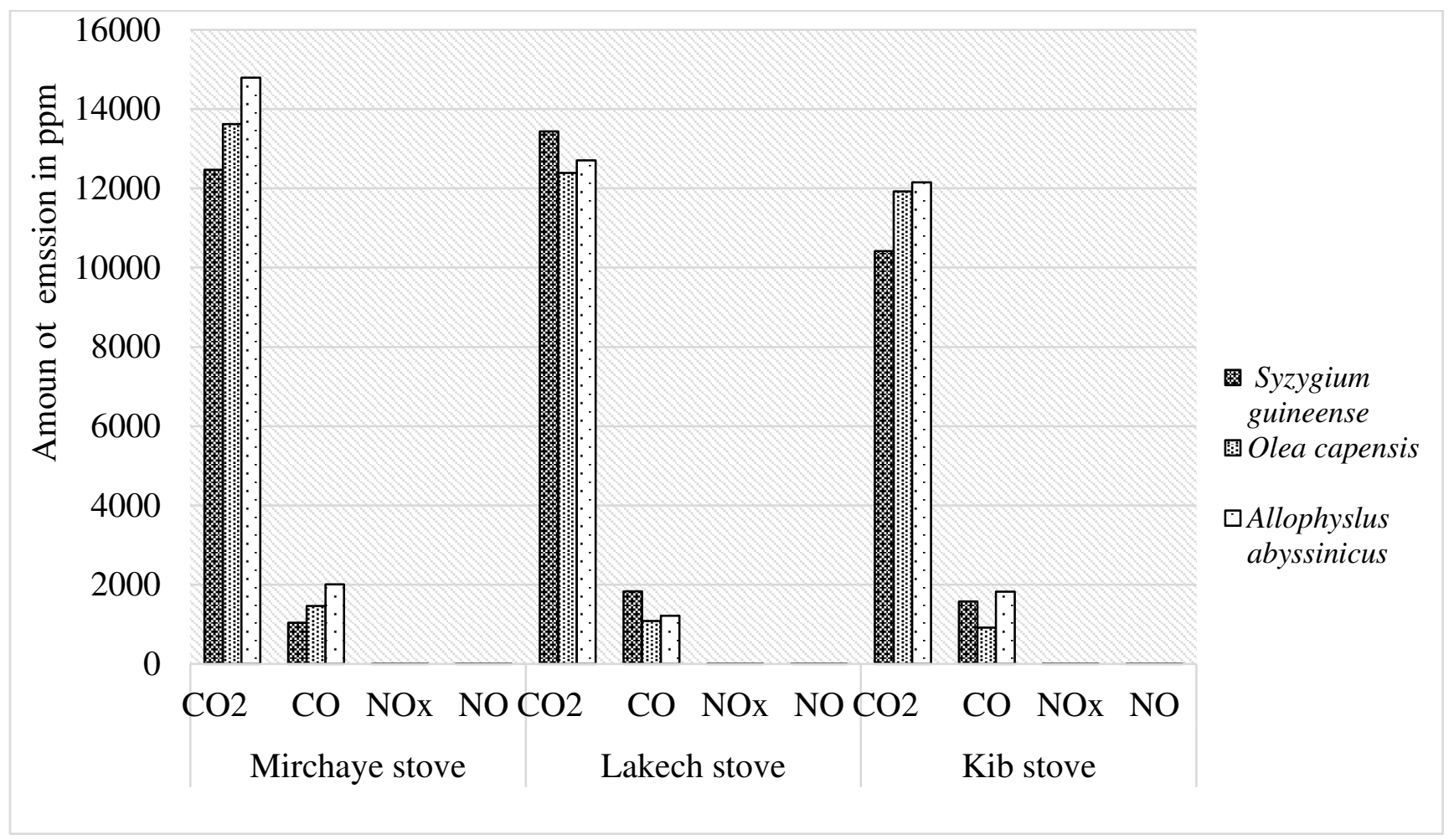

3 Figure 10: Mean CO2, CO, NOx, and NO emission from different charcoal stoves using

4 charcoal produced from Syzygium guineense, Olea capensis, and Allophylus abyssinicus

5 Kib, Lakech, and Mirchaye stoves had a lower potential of emitting greenhouse gases with global

6 warming potential as compared to the traditional metal charcoal stove (Table 9 below). The annual

7 emission of $\mathrm{CO} 2, \mathrm{CO}$, and NOx of Traditional metal stove, Mirchaye, Lakech, and Kib stoves

8 were $77.07,14.64,13.69$, and 12.74 tons of $\mathrm{CO}_{2} \mathrm{e}$ respectively (Table 9). Accordingly, the kib 
1 stove has the potential to mitigate about 64.33ton $\mathrm{CO}_{2} \mathrm{e}(83.23 \%)$ GHGs from being added to the

2 atmosphere due to the burning of charcoal fuel. Similarly, Lakech and Mirchaye stoves mitigate

3 about $63.372(82.23 \%)$ and $62.422(81.00 \%)$ ton/year of greenhouse gases relative to traditional

4 metal charcoal stoves. Surprisingly, these figures are by far higher than the finding of [18] which

5 states that Mirchaye and Lakech charcoal stove has the potential to reduce GHG emission by $25 \%$

6 and $11 \%$ respectively. Even when compared with the research finding of [41] which studies the

7 fuel-saving potential of Lakech and Mert-Kum firewood stoves in Awassa town. These significant

8 differences might be associated with the types of charcoal fuel and variation in the design of

9 charcoal produced at the different localities of the country. The highest greenhouse gas mitigation

10 of charcoal stoves under investigation has a great contribution to reducing the working load on

11 children and women [36], [47], reduce household air pollution, and respiratory diseases [12].

12 Furthermore, in long run using such stoves would contribute to reducing global warming [48], [49]

13 and reduces the pressure on forest resources [50]. The finding of this research also shows that

14 among the locally modified improved charcoal stoves, Mirchaye followed by Lakech stove had a

15 great contribution to GHG emission reduction, and hence, shifting to these technologies has

16 multitudes of importance.

17 Table 9: Percent of emission reduction, total global warming potential and CO2e of different

18 charcoal stoves

\begin{tabular}{|c|c|c|c|c|c|c|c|c|c|c|c|}
\hline & \multicolumn{4}{|c|}{ Emission per cooking } & \multicolumn{4}{|c|}{$\%$ reduction/cooking } & \multicolumn{3}{|l|}{ TGWP/ } \\
\hline & & & & & & & & & /cooking & (ton/da & (ton/ye \\
\hline Stoves & $\mathrm{CO}_{2}$ & $\mathrm{CO}$ & $\mathrm{No}_{\mathrm{x}}$ & $\mathrm{NO}$ & $\mathrm{CO}_{2}$ & $\mathrm{CO}$ & $\mathrm{No}_{x}$ & NO & (g/ton) & y) & ar) \\
\hline $\mathrm{Kib}$ & 11496.67 & 1437.97 & 5.97 & 5.83 & 83.12 & 84.37 & 40.12 & 40.93 & 15852.97 & 0.0175 & 12.739 \\
\hline
\end{tabular}




\begin{tabular}{lccccccccccc} 
Lakech & 12846.67 & 1375.63 & 6.17 & 6.17 & 81.14 & 85.05 & 38.11 & 37.49 & 17017.37 & 0.0188 & 13.694 \\
Mirchaye & 13626.67 & 1503 & 8.87 & 8.53 & 79.99 & 83.66 & 11.03 & 13.58 & 18198.65 & 0.0201 & 14.644 \\
& & & & & & & & & & & \\
\hline $\begin{array}{l}\text { Traditional } \\
z\end{array}$ & 68100.67 & 9200 & 9.97 & 9.87 & & & & & 95771.46 & 0.1056 & 77.066 \\
$z$
\end{tabular}

3 Conclusion and Recommendation

$4 \quad$ The types and efficiency of stoves used by households have a considerable impact on charcoal fuel

5 consumption. The findings revealed that traditional charcoal stoves consume a huge amount of

6 fuel when compared with locally produced modified stoves. Furthermore, there was a difference

7 in emission and fuel-saving between traditional metal stoves and improved stoves that are

8 considered in this study. There were also differences in terms of fuel consumption, fuel-saving,

9 and greenhouse gas emissions among improved stoves. Furthermore, the types of wood used for

10 charcoal preparation, in addition to stoves types, also have an impact on the amount of fuel

11 consumed and pollutants emitted. Generally, this implies that improved stoves have a great

12 contribution in reducing the impact on forest resources, health impacts of indoor air pollution and

13 global warming from the energy sector. Hence, this finding discloses the distribution of these

14 improved stoves for local communities by government and concerned stakeholders so that it

15 enables to assure the objectives of sustainable development goals associated with the provision of

16 affordable and clean energy technologies.

17 Declarations

18 Ethics approval and consent to participate

19 This research is not associated with humans or part of human participation/involvement. Hence, 20 not applicable

21 Consent of publication 
1 The article is original, has not already been published in a journal, and is not currently under

2 consideration by another journal.

3 Conflicting interests

4 The authors declare that they have no competing interests.

\section{$5 \quad$ Fundings}

6 The research is supported by Measuring, Reporting and Verification (MRV) project, Wondo Genet

7 College of Forestry and Natural Resources, Hawassa University, Ethiopia.

\section{Author's contribution}

9 Both the first (GD) and second authors (AD) were involved in the inception of research ideas, data 10 and collection. Moreover, the first author (corresponding author) was also involved in data 11 analysis, interpretation, manuscript development and editing.

12

13 Availability of data and materials

14 The datasets used and/or analyzed during the current study are available from the corresponding 15 author on reasonable request.

\section{Acknowledgment}

17 We would like to thank MRV project office for their financial support during data collection. At 18 the end, but not the least, we also acknowledge the head of the Adola Rede district, and staff 19 members including Anferara and Maleka kebele managers for the unrestricted support during data 20 collection.

References

22 [1] Y. T. Wassie and M. S. Adaramola, "Socio-economic and environmental impacts of rural 23 electrification with Solar Photovoltaic systems: Evidence from southern Ethiopia," Energy

24 Sustain. Dev., vol. 60, pp. 52-66, 2021, doi: 10.1016/j.esd.2020.12.002. 
1 [2] G. Liko, "Impacts of Energy Sector on Economy, Social and Political Landscape, and

Sustainable Development," no. October, pp. 0-13, 2019, doi: 10.13140/RG.2.2.12626.91847.

[3] International Energy Agency, "Global Energy Review 2021," Glob. Energy Rev. 2020, 2021, [Online]. Available: https://iea.blob.core.windows.net/assets/d0031107-401d-4a2fa48b-9eed19457335/GlobalEnergyReview2021.pdf.

[4] O. P. Kurmi, K. B. H. Lam, and J. G. Ayres, "Indoor air pollution and the lung in low- and medium-income countries," Eur. Respir. J., vol. 40, no. 1, pp. 239-254, 2012, doi: 10.1183/09031936.00190211.

[5] BP, "Energy Outlook 2020 edition explores the forces shaping the global energy transition out to 2050 and the surrounding that," BP Energy Outlook 2030, Stat. Rev. London Br. Pet., p. 81, 2020, [Online]. Available: https://www.bp.com/content/dam/bp/businesssites/en/global/corporate/pdfs/energy-economics/energy-outlook/bp-energy-outlook2020.pdf.

[6] S. Keles, S. Bilgen, and K. Kaygusuz, "Biomass energy source in developing countries," vol. 6, no. June, pp. 566-576, 2017.

[7] B. Town and D. Berhan, "Supply and Consumption of Household Energy in Central Ethiopia: The Case Supply and Consumption of Household Energy in Central Ethiopia : The Journal of Fundamentals of,” no. November, 2018, doi: 10.4172/2090-4541.1000269.

[8] F. J. Rello, A. Valero, and F. J. Adroher, "Anisakid parasites of the pouting (Trisopterus luscus) from the Cantabrian Sea coast, Bay of Biscay, Spain," J. Helminthol., vol. 82, no. 4, pp. 287-291, 2008, doi: 10.1017/S0022149X08006196.

[9] Y. T. Wassie, M. M. Rannestad, and M. S. Adaramola, "Determinants of household energy 
choices in rural sub-Saharan Africa: An example from southern Ethiopia,” Energy, vol. 221, p. 119785, 2021, doi: 10.1016/j.energy.2021.119785.

[10] D. Abebaw, "Household Determinants of Fuelwood Choice in Urban Ethiopia : A Case Study of Jimma Town. The Journal of Developing Areas 41(1) 117-126," J. Dev. Areas, vol. 41, no. 1, pp. 117-126, 2020.

[11] Mulatu Mengist, "Households Fuelwood Consumption Impact on Forest Degradation in the Case of Motta District, Northwest Ethiopia," EPRA Int. J. Res. Dev., no. October, pp. 308315, 2020, doi: 10.36713/epra4763.

[12] M. M. Adane, G. D. Alene, and S. T. Mereta, "Biomass-fuelled improved cookstove intervention to prevent household air pollution in Northwest Ethiopia: a cluster randomized controlled trial," Environ. Health Prev. Med., vol. 26, no. 1, pp. 1-15, 2021, doi: 10.1186/s12199-020-00923-z.

[13] F. Sedano et al., "The impact of charcoal production on forest degradation: A case study in Tete, Mozambique," Environ. Res. Lett., vol. 11, no. 9, 2016, doi: 10.1088/17489326/11/9/094020.

[14] A. P. Zidago and Z. Wang, "Charcoal and Fuelwood Consumption and Its Impacts on Environment in Cote d'Ivoire (Case Study of Yopougon Area)," Environ. Nat. Resour. Res., vol. 6, no. 4, p. 26, 2016, doi: 10.5539/enrr.v6n4p26.

[15] J. E. Hodbod, "The Impacts of Biofuel Expansion on the Resilience of Social-Ecological Systems in Ethiopia Jennifer Elizabeth Hodbod A thesis submitted for the degree of Doctor of Philosophy to the School of Environmental Sciences of the University of East Anglia July 2," no. July, 2013.

[16] U. Alemayehu Zeleke and F. Motuma Tolera, "Estimation of Households Fuelwood 
Consumption and Its Carbon Dioxide Emission: A Case Study on Adaba District South East Ethiopia," Http://Www.Sciencepublishinggroup.Com, vol. 7, no. 4, p. 92, 2019, doi: 10.11648/j.jenr.20180704.11.

[17] S. Baral et al., "Factors affecting fuelwood consumption and CO2 emissions: An example from a community-managed forest of Nepal," Energies, vol. 12, no. 23, 2019, doi: 10.3390/en12234492.

[18] F. Mamuye, B. Lemma, and T. Woldeamanuel, "Emissions and fuel use performance of two improved stoves and determinants of their adoption in Dodola, southeastern Ethiopia," Sustain. Environ. Res., vol. 28, no. 1, pp. 32-38, 2018, doi: 10.1016/j.serj.2017.09.003.

[19] O. Ekeh, A. Fangmeier, and J. Müller, "Quantifying greenhouse gases from the production , transportation and utilization of charcoal in developing countries : a case study of Kampala , Uganda,” no. September, 2014, doi: 10.1007/s11367-014-0765-7.

[20] Ö. Ipek and E. Ipek, "Effects of indoor air pollution on household health: evidence from Turkey,” Environ. Sci. Pollut. Res., no. Smith 1987, 2021, doi: 10.1007/s11356-021-151759.

[21] B. S. James, R. S. Shetty, A. Kamath, and A. Shetty, "Household cooking fuel use and its health effects among rural women in southern India-A cross-sectional study," PLoS One, vol. 15, no. 4, pp. 1-12, 2020, doi: 10.1371/journal.pone.0231757.

[22] E. Dresen, B. Devries, M. Herold, L. Verchot, and R. Müller, "Fuelwood Savings and Carbon Emission Reductions by the Use of Improved Cooking Stoves in an Afromontane Forest, Ethiopia,” pp. 1137-1157, 2014, doi: 10.3390/land3031137.

[23] J. Zhang et al., "Greenhouse gases and other airborne pollutants from household stoves in China: A database for emission factors," Atmos. Environ., vol. 34, no. 26, pp. 4537-4549, 
2000, doi: 10.1016/S1352-2310(99)00450-1.

[24] M. M. Adane, G. D. Alene, S. T. Mereta, and K. L. Wanyonyi, "Effect of improved cookstove intervention on childhood acute lower respiratory infection in Northwest Ethiopia : a cluster- randomized controlled trial,” pp. 1-13, 2021.

[25] R. Bailis et al., "Performance testing for monitoring improved biomass stove interventions: experiences of the Household Energy and Health Project This paper is one of six describing work done as part of the Household Energy and Health (HEH) Project," Energy Sustain. Dev., vol. 11, no. 2, pp. 57-70, 2007, doi: 10.1016/S0973-0826(08)60400-7.

[26] S. H. Kooser, "Clean Cooking: The Value of Clean Cookstoves in Ethiopia," J. Environ. Resour. Econ. Colby, vol. 01, no. 01, pp. 1-21, 2014, [Online]. Available: http://digitalcommons.colby.edu/jerec/vol01/iss01/3.

[27] B. Garedew and L. Simon, "Survey of Charcoal Production and its Impact on Plant Diversity and Conservation Challenges in Abeshige District, Gurage Zone, Ethiopia," vol. 6, no. 3, 2018, doi: 10.4172/2332-2543.1000221.

[28] F. Babalola, F. D. Babalola, and E. E. Opii, "Factors influencing consumption of charcoal as household energy in Benue State, Nigeria," Int. J. Org. Agric. Res. Dev., vol. 6, no. October 2012, 2012, [Online]. Available: https://www.researchgate.net/publication/282152027.

[29] M. Negash and G. Kelboro, "Effects of Socio-Economic Status and Food Consumption Pattern on Household Energy uses: Implications for Forest Resource Degradation and Reforestation around Wondo Genet Catchments ... Effects of Socio-Economic Status and Food Consumption Pattern on Hous," no. November, 2014, doi: 10.1353/eas.2014.0001.

[30] T. Yayeh, A. Guadie, and S. Gatew, "Adoption and fuel use efficiency of mirt stove in Dilla 
district, southern Adoption and fuel use efficiency of mirt stove in Dilla district, southern Ethiopia," Clean. Eng. Technol., vol. 4, no. July, p. 100207, 2021, doi: 10.1016/j.clet.2021.100207.

[31] Tinsae Bahru, "Indigenous knowledge on fuel wood (charcoal and/or firewood) plant species used by the local people in and around the semi-arid Awash National Park, Ethiopia,” J. Ecol. Nat. Environ., vol. 4, no. 5, 2012, doi: 10.5897/jene11.105.

[32] D. F. Barnes, K. Openshaw, K. R. Smith, and R. Van Der Plas, What Makes People Cook with Improved Biomass Stoves? A Comparative Internation Review of Stove programs, no. 242. World Bank Tec, 2015.

[33] Z. C. Win et al., "Conversion and Emission Factors - woodfuel," Forests, vol. 10, no. 12, pp. 1-12, 2018, doi: 10.3390/su10124367.

[34] K. D. Adem and D. A. Ambie, "A review of injera baking technologies in Ethiopia: Challenges and gaps," Energy for Sustainable Development, vol. 41. International Energy Initiative, pp. 69-80, 2017, doi: 10.1016/j.esd.2017.08.003.

[35] J. Tryner, A. J. Marchese, and B. D. Willson, "The effects of fuel type and geometry on emissions and efficiency of natural draft semi-gasifier biomass cookstoves," 8th US Natl. Combust. Meet. 2013, vol. 4, no. 970, pp. 3542-3556, 2013.

[36] R. Alirigia, "Fuelwood Coolection and Children's School Attendance in the KassenaNankani Districts of Northern Ghana,” pp. 1-69, 2019.

[37] E. Bloomfield, "Gender and Livelihoods Impacts of Clean Cookstoves in South Asia Study i Gender and Livelihoods Impacts of Clean Cookstoves in South Asia Commissioned and Supported By: Global Alliance for Clean Cookstoves Gender and Livelihoods Impacts of Clean Cookstove," 2014. 
[38] E. Dresen, B. DeVries, M. Herold, L. Verchot, and R. Müller, "Fuelwood savings and carbon emission reductions by the use of improved cooking stoves in an afromontane forest, Ethiopia," Land, vol. 3, no. 3, pp. 1137-1157, 2014, doi: 10.3390/land3031137.

[39] M. Sharma and S. Dasappa, "Emission reduction potentials of improved cookstoves and their issues in adoption : An Indian outlook," J. Environ. Manage., vol. 204, pp. 442-453, 2017, doi: 10.1016/j.jenvman.2017.09.018.

[40] M. Rasoulkhani and M. Ebrahimi-nik, "Comparative evaluation of the performance of an improved biomass cook stove and the traditional stoves of Iran Sustainable Environment Research Comparative evaluation of the performance of an improved biomass cook stove and the traditional stoves of Iran," Sustain. Environ. Res., no. October, 2018, doi: 10.1016/j.serj.2018.08.001.

[41] Z. D. Yigezu and T. O. Jawo, "Empirical analysis of fuelwood consumptions and its environmental implications in rural sub-city, Southern Ethiopia," Int. J. Sustain. Energy, vol. 40, no. 5, pp. 448-459, 2021, doi: 10.1080/14786451.2020.1812609.

[42] Z. Gebreegziabher, A. D. Beyene, R. Bluffstone, P. Martinsson, A. Mekonnen, and M. A. Toman, "Fuel savings, cooking time and user satisfaction with improved biomass cookstoves: Evidence from controlled cooking tests in Ethiopia," Resour. Energy Econ., vol. 52, pp. 173-185, 2018, doi: 10.1016/j.reseneeco.2018.01.006.

[43] A. A. Biratu, "The Implication of Wood-Burning Stove Efficiency for Environment, Health and CO2 emissions in the Jogo- gudedo Watershed , Ethiopia," vol. 4, no. July, pp. 154163, 2016, doi: 10.14662/ARJASR2016.019.

[44] D. G. Fullerton, N. Bruce, and S. B. Gordon, "Indoor air pollution from biomass fuel smoke is a major health concern in the developing world," Trans. R. Soc. Trop. Med. Hyg., vol. 
102, no. 9, pp. 843-851, 2008, doi: 10.1016/j.trstmh.2008.05.028.

[45] N. Bruce et al., "Impact of improved stoves, house construction and child location on levels of indoor air pollution exposure in young Guatemalan children," J. Expo. Anal. Environ. Epidemiol., vol. 14, no. SUPPL. 1, 2004, doi: 10.1038/sj.jea.7500355.

[46] G. Y. Obeng, E. Mensah, G. Ashiagbor, O. Boahen, and D. J. Sweeney, “energies Watching the Smoke Rise Up : Thermal Efficiency, Pollutant Emissions and Global Warming Impact of Three Biomass Cookstoves in Ghana," pp. 1-14, 2017, doi: 10.3390/en10050641.

[47] S. Bwenge, "The Effects of Adopting Improved Wood Stoves on the Welfare of Rural Women: A case of Kibaha District in Tanzania," Van Hall Larenstein Univ. Appl. Sci. Netherlands, pp. 1-39, 2011.

[48] C. Parker, P. Keenlyside, H. Galt, F. Haupt, and T. Varns, "Linkages between cookstoves and REDD+. A report for the Global Alliance for Clean Cookstoves.," Glob. Alliance Clean Cookstoves, no. March, p. 50, 2015.

[49] N. MacCarty, D. Ogle, D. Still, T. Bond, and C. Roden, "A laboratory comparison of the global warming impact of five major types of biomass cooking stoves," Energy Sustain. Dev., vol. 12, no. 2, pp. 56-65, 2008, doi: 10.1016/S0973-0826(08)60429-9.

[50] S. N. Lisboa, R. Mate, A. Manjate, and A. Sitoe, "Applying the icat sustainable development methodology to assess the impacts of promoting a greater sustainability of the charcoal value chain in mozambique," Sustain., vol. 12, no. 24, pp. 1-28, 2020, doi: $10.3390 /$ su122410390. 